OPEN ACCESS

Edited by:

Ali Khosravanipour Mostafazadeh,

Centre d'études des procédés

chimiques du Québec

(CÉPROCQ), Canada

Reviewed by:

Mehrdad Taheran,

Centre National en Électrochimie et en

Technologie Environnementales

Inc, Canada

Agnieszka Cuprys,

Norwegian University of Life

Sciences, Norway

*Correspondence:

Hubert Cabana

Hubert.Cabana@USherbrooke.ca

Specialty section

This article was submitted to Water and Human Systems,

a section of the journal

Frontiers in Water

Received: 23 June 2021

Accepted: 22 September 2021

Published: 22 October 2021

Citation:

Vaithyanathan VK and Cabana H (2021) Integrated Biotechnology Management of Biosolids: Sustainable

Ways to Produce Value-Added

Products. Front. Water 3:729679.

doi: 10.3389/frwa.2021.729679

\section{Integrated Biotechnology Management of Biosolids: Sustainable Ways to Produce Value-Added Products}

\author{
Vasanth Kumar Vaithyanathan and Hubert Cabana* \\ Université de Sherbrooke Water Research Group, Department of Civil and Building Engineering, Université de Sherbrooke, \\ Sherbrooke, QC, Canada
}

Biosolids (BS) are organic dry matter produced from wastewater treatment plants (WWTPS). The current yearly worldwide production of BS is estimated to be around 100-125 million tons and is expected to continuously increase to around 150-200 million tons by 2025. Wastewater treatment industries across the globe strive to achieve a green and sustainable manufacturing base for the management of enormous amounts of municipal BS, which are rich in nutrients and organic dry matter along with contaminants. The management of these organic-rich wastes through environmentally friendly recovery technologies is a major challenge. The need to improve waste biomass disposal by biological development and develop more economically viable processes has led to a focus on the transformation of waste resources into value-added products (VAP). This paper assesses the leading disposal methods (based on volume and contaminant reduction) and reviews the state of biotechnological processes for VAP recovery from municipal wastewater sludge (untreated solid waste residual) and BS (stabilized solid waste which meets criteria for its use in land). A review of the anaerobic and aerobic digestion processes is presented to provide a holistic overview of this growing research field. Furthermore, the paper also sheds light on the pollutant reduction and resource recovery approaches for enzymes, bioflocculants, bioplastics, biopesticides, and biogas as a mean to represent BS as a potential opportunity for WWTPs. However, only a few technologies have been implemented for VAP resource recovery and a shift from WWTPs to waste resource recovery facilities is still far from being achieved.

Keywords: biosolids, sludge, aerobic digestion, value-added products, contaminants

\section{INTRODUCTION}

Biosolids (BS) are nutrient-rich organic dry matter produced from wastewater treatment plants (WWTPs). Apart from their nutrient content, BS are also rich in microbial sources, pathogens, organic and inorganic contaminants (Marguí et al., 2016; Fijalkowski et al., 2017). There are many published works that describe the production of these solid wastes around the globe (Verlicchi and Zambello, 2015; Kumar et al., 2017; Sharma et al., 2017; Gao et al., 2020; Mohajerani and Karabatak, 2020; Vaithyanathan et al., 2020). The amount of BS produced annually worldwide has increased dramatically due to the construction of treatment plants and upgrading of existing 
facilities as a result of increased water demand and WWTP regulations (Suksiripattanapong et al., 2015). Currently, the worldwide production of BS is estimated to be around 100-125 million tons and is expected to continuously increase to around 150-200 million tons by 2025 (Mohajerani et al., 2017). The high volume of municipal and industrial BS produced all over the world is a major cause of concern to environmentalists these days. At the current global population growth rate, the generation of solid wastes like BS is bound to increase dramatically. Canada produces 660,000 dry tons of biosolids annually (CCME, 2012; Jin et al., 2018; Vaithyanathan et al., 2021b). These BS are either disposed of or used in land applications (CCMEA, 2010; Gherghel et al., 2019). To promote the beneficial use of the otherwise discarded BS, the Canadian Council of Ministers of Environment (CCME) has reviewed and published the accepted methods of BS treatment. According to this report, dewatering, drying in rotary vacuum dryers and nutrient recovery from wastewater is employed to improve the quality of BS produced (CCMEA, 2010).

The enormous quantity of BS produced from WWTPs always poses difficulties for environmental scientists and engineers due to the handling and disposal processes and thus, its management requires careful consideration (Ahmad et al., 2017). The presence of contaminants and pathogens in BS, which are hazardous to human and animal health, makes government bodies rethink their use in agricultural land application. Alongside the waning of traditional BS disposal routes, due to mounting pressure from the public, there is a great demand for environmentally acceptable and cost effective alternative routes (Saetea and Tippayawong, 2013).

Generation of these solid wastes is increasing due to rapid global urbanization and has created a threat to the environment, forcing public/private solid waste generators to rethink current BS management strategies (Tyagi and Lo, 2013). Furthermore, an increasing demand of primary energy due to the depletion of fossil fuel reserves along with the combination of various scenarios such as climate change, public awareness and recent advancements in technology have driven the attention toward renewable energy (Tyagi and Lo, 2013). Moreover, from an industrial point of view, manufacturing of commercial microbialbased value-added products (VAP) requires an inexpensive route and availability of abundant raw materials throughout the year without any supply disruption. Considering these facts, BS could serve as a prominent viable option as raw material in industries. Microbial strain selection and proper choice of appropriate technologies for pre-treatment, fermentation, harvesting and recovery are the best ways to achieve a higher yield of VAP, which also introduces a circular economy to WWTPs (Barnabé et al., 2009; Cao et al., 2020). Nevertheless, high energy input and operating costs for recovery, minimal market prices and social unacceptability are major obstacles for the development and implementation of BS resource recovery technologies (Cao et al., 2020). So, the recovered resources with high economic value, market demand, and moreover with public acceptance, thus the, current attention has focused on these techniques (Xue et al., 2019; Cao et al., 2020).
BS can be described as a heterogenous matrix consisting of bacterial constituents such as proteins, lipids, cellulose coupled with inorganic matter, other organic matter, pathogens, and organic and inorganic pollutants. Disposal of BS with the presence of many biohazardous components, pathogens, and chemical contaminants into the soil via land application/landfilling can lead to widespread environmental problems due to their potential toxicity, carcinogenicity, mutagenicity and ability to be bioaccumulated in the food chain (Barnabé et al., 2009). Specific regulations must be fulfilled when disposing BS for land application. Different countries have implemented limits on the occurrence of heavy metals, linear alkyl alkynoates, polycyclic aromatic hydrocarbons (PAHs), polychlorinated biphenyls (PCBs) and phthalates in BS and monitor their impacts while applied on land (Mininni et al., 2015; Fijalkowski et al., 2017; Delibacak et al., 2020). However, no limits have been proposed for most of the trace organic contaminants (TrOCs) present in BS (Verlicchi and Zambello, 2015).

TrOCs such as pesticides, industrial chemicals, hormones, PhACs like antibiotics, antimicrobial agents, non-steroidal antiinflammatory drugs and other organic pollutants pose a major threat as they induce direct biological action in the living system (Semblante et al., 2015; Rathankumar et al., 2020). Subsequently, a bioaccumulation of antibiotics in plants has been reported due to a direct application of contaminant-containing BS (Rathankumar et al., 2020). A risk quotient evaluation of the common pharmaceuticals found in BS concluded that penicillin, tetracycline, macrolide, quinolone, trimethoprim and sulfonamides pose the maximum risk in the environment, such as hindering the soil ecosystem, inducing antibiotic resistance in microorganisms and affecting soil lifeforms (Rathankumar et al., 2020). Moreover, TrOCs which were released into the environment through anthropogenic activities and their "natural levels" continue to increase due to urbanization and industrialization (Verlicchi et al., 2012; Rathankumar et al., 2020).

BS containing pathogens and hazardous contaminants affect the soil vegetation and ground water level, so proper treatment and disposal of BS are necessary to protect the environment; this disposal could represent up to $50 \%$ of the total operating cost of WWTPs (Rathankumar et al., 2020; Vaithyanathan et al., 2021b). Moreover, BS disposal could be responsible for up to $40 \%$ of greenhouse gases (GHG) emissions from WWTPs (Qian et al., 2016; Gherghel et al., 2019). Meanwhile, BS, which are a considerable source of energy and resources, can be used as an alternative for non-renewable resources, which produce the same amount of energy but have an adverse impact on the environment (Fijalkowski et al., 2017).

The solution for the above-mentioned issue is a sustainable circular economy. The major principle involved in a circular economy is recycling and reuse of products for design and optimization (González-García et al., 2019). It replaces the "end of life concept" with restoration, by eliminating the use of toxic chemicals and shifting toward the use of renewable energy and resources (EMF, 2015). Moreover, reutilizing municipal waste to gain energy or resources and then disposing that waste, has 


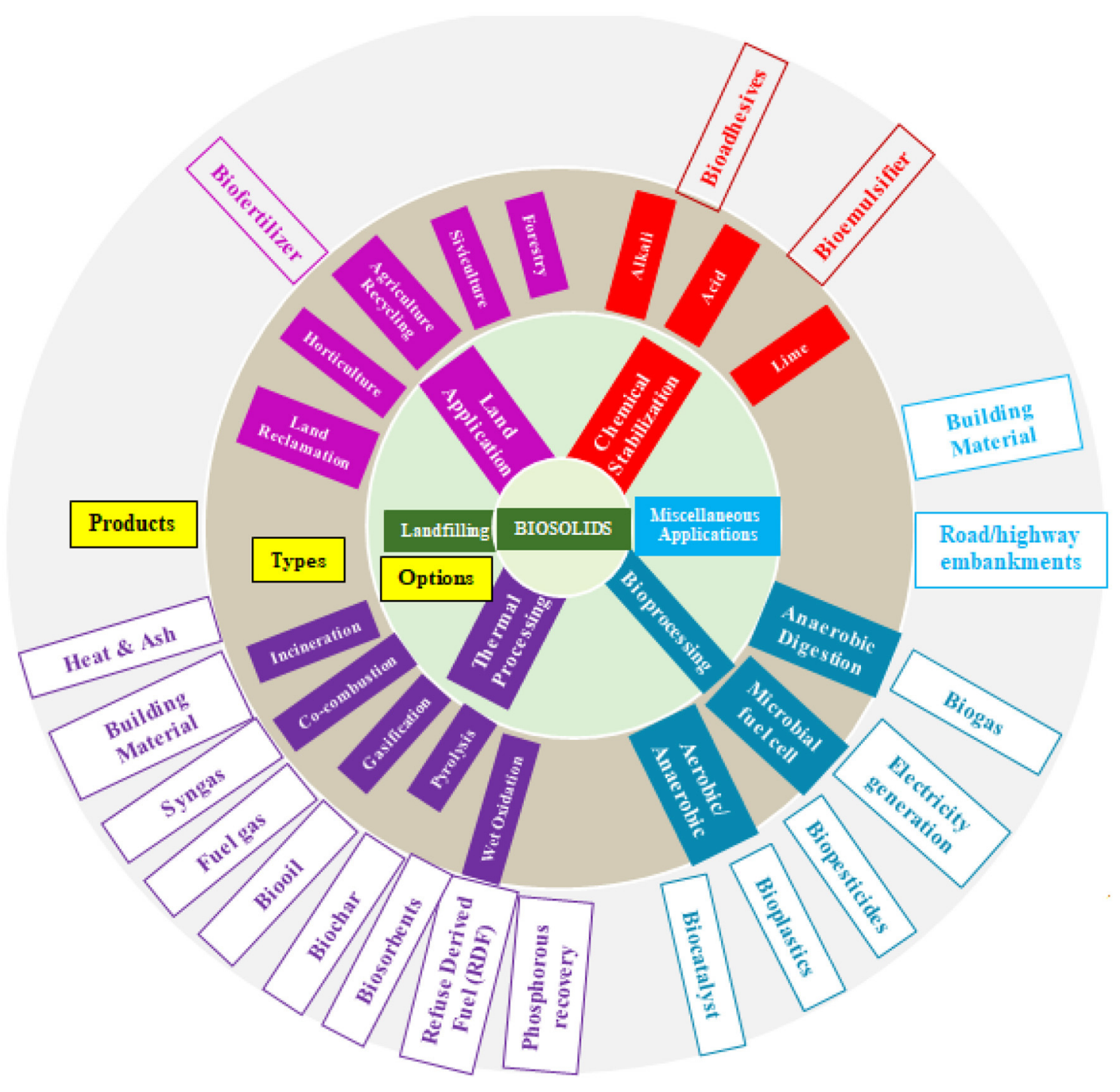

FIGURE 1 | Different solid waste management options for biosolids (Adapted from Sharma et al., 2017).

reduced adverse effects on the environment as well as boosted economic growth (González-García et al., 2019). In addition, it has created more job opportunities by converting residual municipal waste into high valued resources such as biogas, biopolymers, building aggregates etc. (Figure 1) (Gherghel et al., 2019).

In the context of a circular economy, VAP obtained as energy from waste can be a substitute for existing energy resources and reduce the associated $\mathrm{CO}_{2}$ emissions (Gherghel et al., 2019). Sustainable management of BS is about developing innovative technologies to harness the benefits by maximizing waste utilization while considering appropriate social, economic and environmental conditions of the site localization (Fijalkowski et al., 2017). BS-based VAPs, free of contaminants, are important for protecting biodiversity and addressing the public concern over the beneficial uses of BS (Barnabé et al., 2009).
In this paper, solid waste from WWTPs is differentiated into two types: biosolids, defined as a stabilized solid waste, which meets land application and sludge criteria or unstabilized or undigested solid waste residual. For the past 20 years, work on solid waste management has been growing and this paper summarizes the various resources, which can be recovered from BS and sludge. Furthermore, the paper focuses on volume reduction and TrOCs removal from BS and sludge. This paper also covers the recent developments in waste valorization and VAP production for the period from 2008 to 2020.

\section{NUTRIENTS CONTENT AND ORGANIC CONTAMINANTS IN BIOSOLIDS}

Depending on the treatment process, BS are usually comprised of $45-70 \%$ organic matter with $1-7 \%$ nitrogen and $\leq 4 \%$ 
calcium, sulfur, phosphorus, magnesium and potassium, which can serve as an extensive source of nutrients for both plants and microorganisms, and can improve soil quality when applied on the land (Sullivan et al., 2015; Sharma et al., 2017; Brown et al., 2020). Depending on the application rate, the response of BS nitrogen is similar to or greater than that of synthetic nitrogen. The concentration of BS phosphorus exceeds crop demands, but its bioavailability is low and has less environmental impact when compared to synthetic phosphorus. The concentration of potassium in BS is low, however, since potassium is highly soluble and is partitioned more into the effluent than into the BS. However, BS have a full source of essential plant nutrients like nitrogen, phosphorus, and potassium, which are helpful in crop fertility (Brown et al., 2020). The carbon and nutrients contained in BS have value both independently and in combination. Fixed carbon can be used as a source of energy or as a soil conditioner (Sharma et al., 2017).

For several years, there has been a growing concern regarding emerging contaminants of interest in BS and effluents from WWTPs (Luo et al., 2014; Gonzalez-Gil et al., 2016). Several major categories have been reported as substances of concern in BS (WEAO, 2010). These include industrial chemicals (pesticides, plasticizers, and alkylbenzene sulfonates, etc.), alkyl phenols, flame retardants, hormones, pharmaceuticals, personal care products, certain metals (arsenic, mercury, silver, and selenium, etc.), polycyclic aromatic hydrocarbons, polychlorinated dioxins and furans, and pathogens (Rathankumar et al., 2020). However, their environmental fate and significance is not known or well-understood (Kinney et al., 2006; CCMEA, 2010).

Presence of above mentioned emerging contaminants such as pharmaceuticals and personal care products in sewage sludge were tested in nationwide by US Environmental Agency. Out of the 72 pharmaceutical and personal care products that were tested for in BS, triclosan and triclocarban top the list with concentrations of $>1,000 \mathrm{mg} / \mathrm{kg}$ (USEPA, 2009). The hydrophobic antimicrobial agents, triclosan and triclocarbans, have been reported to be present in effluents and BS in concentrations that pose a threat of bioaccumulation in snails and earthworms (Coogan and Point, 2008; Higgins et al., 2011). The environmental persistence of these agents is mainly due to the incomplete removal by biodegradation in wastewater treatment systems. The endocrine disruptive nature and bioaccumulation in snails and algae proves that the existence of these compounds in the environment is a serious issue (Coogan et al., 2007; Ahn et al., 2008). Contaminated BS applications on land fields have been reported to induce antibiotic resistance in microbes and also affect earthworms and horsetails (Ernervik, 2011). Bisphenol-A (BPA) leaches from the polycarbonate and epoxy resins, and is found in the surface water and BS. On assessing the BPA levels in North America, high concentrations in the range of $0.197-36.7 \mathrm{mg} / \mathrm{kg}$ were found in Canada (Lee and Peart, 2000). Though they have lesser half-lives in soil and are efficiently degraded, the anti-androgenic properties and evidences of their toxicity to plants and invertebrates and their endocrine disruptive nature in mammals have been reported (Tyl et al., 2002; Klečka et al.,
2009). Due to their hydrophobicity, polyaromatic hydrocarbons (PAHs) are emerging as one of the priority contaminants found in soil. PAH degradation in BS amended soil is slow due to their low bioavailability and high molecular weight (Baran et al., 2003; Haynes et al., 2009). Limits for PAH concentrations in BS have been assigned in the $\mathrm{EU}$; the maximum allowable concentration is $6 \mathrm{mg} / \mathrm{kg}$ (USEPA, 2009).

With the increasing energy demand and lack of supply, the need for the sustainable development of these resource-rich BS toward environmentally sound solid waste management becomes unavoidable (Pappu et al., 2007). The contaminants in the BS, however, can damage the soil ecosystem, pollute the surface water, groundwater and land, contaminate food chains etc., making them unsuitable for disposal without prior treatment. As the physico-chemical nature of the BS is purely dependent on the nature of the wastewater, which may vary with seasonal and treatment processes, the digested sludge must be analyzed properly prior to land applications (Sharma et al., 2017). BS which have gone through various treatment processes to become solid residue, high in nutrient content and organic matter, can then be utilized for various applications.

\section{BIOSOLIDS MANAGEMENT AND DISPOSAL}

Sludge produced by a WWTP is transported to a sludge treatment line for further treatment; but this process depends on the type and size of the WWTP. The final output of the sludge treatment process is stabilized solid residue containing organic matter, known as BS (Bianchini et al., 2015). However, because of infrastructure and financial restrictions, most developing countries and a few developed countries lack proper sludge management processes (Wainaina et al., 2020). Conventional technologies for sludge management are landfill, incineration, aerobic or anaerobic digestion. Depending on the characteristics of the BS, they can be transported directly to landfills, converted into fertilizer or incinerated (Cerda et al., 2018). However, lower land availability, operating costs and strict regulations have resulted in processes like landfilling being banned and discouraged in some European and North American countries (Kor-Bicakci and Eskicioglu, 2019). However, landfill is mostly applied as a management technique in many developing countries and, incineration in most developed countries (Wainaina et al., 2020). Compared to various technologies, biological processes are economically feasible because of lower energy consumption, low-cost investment, and efficient organic removal rates (Siddique and Wahid, 2018). Biological treatment for BS stabilization can be achieved by either anaerobic or aerobic digestion. Indigenous microorganisms in the $\mathrm{BS}$ are able to withstand stressful environments and utilize the nutrients, thereby converting these wastes into valuable energy or resources through digestion (Wainaina et al., 2020). Anaerobic digestion is a widely used approach; however some treatment plants prefer aerobic digestion due to its social acceptability, effective contaminant removal and enhanced nutrient removal (Vaithyanathan et al., 2021a). 


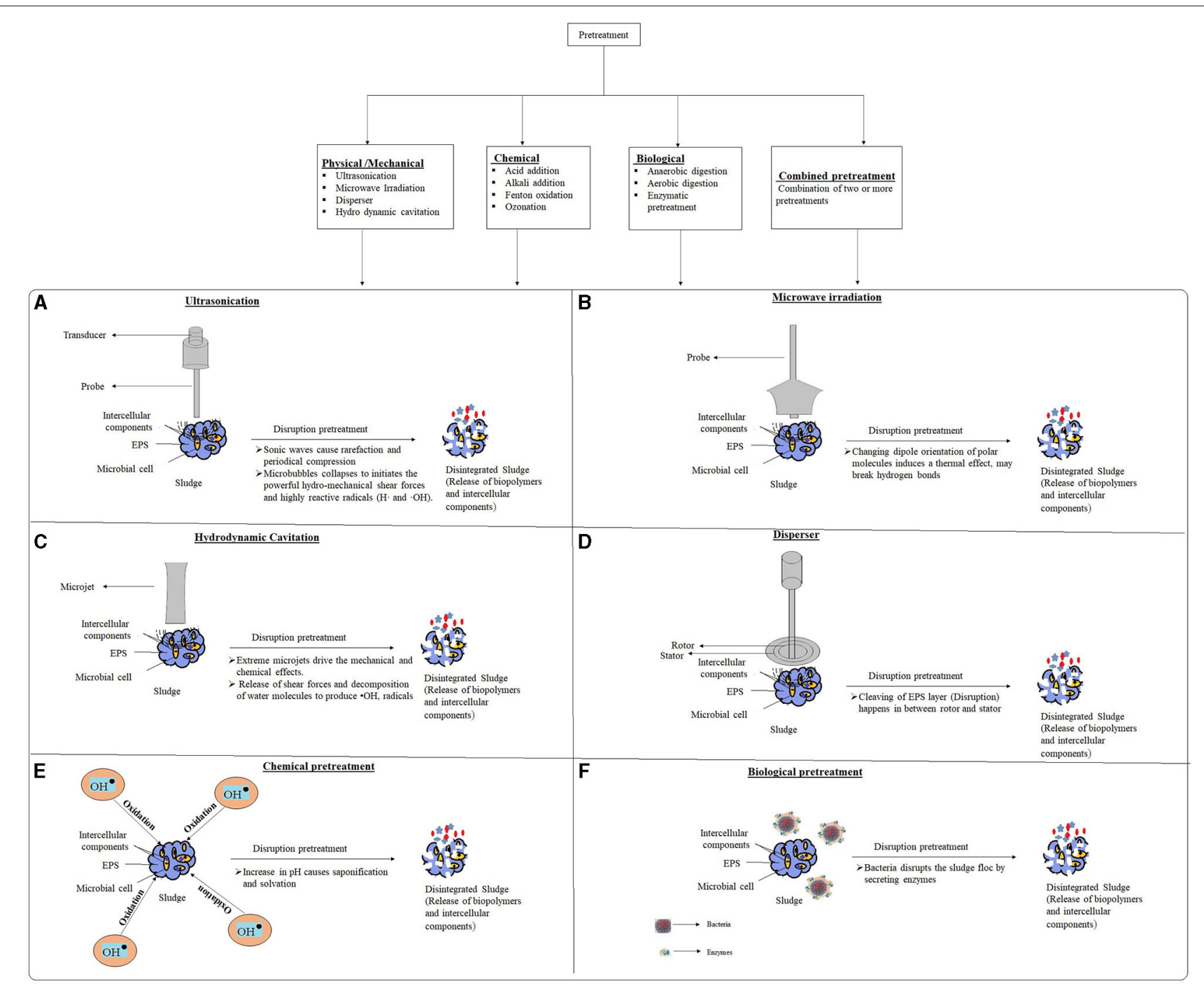

FIGURE 2 | Various pretreatment techniques and mechanisms for different pretreatment methods. (A) Ultrasonication, (B) microwave irradiation, (C) hydro dynamic cavitation, (D) disperser, (E) chemical, and (F) biological pretreatment (Adapted from Guan et al., 2018; Mancuso et al., 2020; Banu et al., 2021).

\section{Pretreatment-An Effective Technique for Enhancing Municipal Solid Waste Solubilization}

The handling and disposal of BS is considered to be one of the biggest challenges due to the enormous volume and high moisture content level $(80 \%)$ of BS. They also contain a substantial amount of biomass, such as carbohydrates, proteins, and lipids, along with various pollutants. The cost of BS management accounts for up to $60 \%$ of the entire operating costs of the WWTP (Coma et al., 2013). Consequently, the volume of BS has to be reduced using various treatment methods in order to meet the proper disposal standards and to reduce the operating costs of municipal WWTPs (Gayathri et al., 2015). Sludge biodegradability is limited due to its complex nature (Kavitha et al., 2014b). The rigid arrangement of microbial cell walls and membranes also forms a barrier in sludge digestion by forming a protective layer which hinders the permeation of hydrolytic enzymes.

In aerobic or anaerobic digestion, nutrient-rich BS are converted into energy or bioproducts and stable organic residue is obtained (Wainaina et al., 2020). However, in the biological process, hydrolysis is the rate-limiting step because extracellular enzymes produced by indigenous microorganisms are immobilized inside the floc, which makes them unavailable for the hydrolysis of readily available and large organic matter, which in turn affect the stabilization of BS (Vaithyanathan et al., 2021b).

Pretreatment (PT) techniques were employed to overcome the above-mentioned problem, and fragmentation processes were applied to disrupt the cell walls in the sludge floc structure and push the organic material from the inner layer 
to the outer layer, making it readily available for microbial degradation during the biological process (Anjum et al., 2016; Wainaina et al., 2020). Enhanced biodegradability, increased organic loading rate, reduced sludge volume and odor reduction are the some of the merits of this PT process (Pilli et al., 2015; Barber, 2016; Wainaina et al., 2020). PT can be either mechanical, chemical, enzymatic or combinations thereof. This part of the section discusses the impact of PT before biological processing of sludge (Figure 2). VAP recovery, contaminant removal and volume reduction that occurred during various PTs of sludge are listed in Table 1. During mechanical PT, breakdown of floc particles increases the specific surface area, which subsequently provides better contact with substrate and indigenous microorganisms thus enhancing anaerobic digestion (Jain et al., 2015). The mechanical PT encompasses an extensive range of processes such as ultrasonication, microwave, freezethaw, thermal, hydrodynamic cavitation.

Ultrasonic PT is applied as it mechanically disrupts the cell structure and low frequencies of $20-40 \mathrm{kHz}$ are effective in sludge treatment (Chu et al., 2002). However, high energy input is required for thorough cell lysis (Chu et al., 2002). Sonic waves produced during ultrasonication cause rarefaction and periodical compression when propagating through the medium. During this process, microbubbles form which collapse when they reach critical size which in turn initiates the powerful hydro-mechanical shear forces and highly reactive radicals $(\mathrm{H}$. and $\cdot \mathrm{OH})$. These shear forces and reactive radicals are responsible for the breakup of sludge flocs and release of intercellular materials (Kesari et al., 2011) (Figure 2). Salsabil et al. (2010) compared three different sludge PTs; ozonation, thermal and ultrasonication. Of the three, ultrasonication is very effective in total suspended solids (TSS) reduction (47\%) followed by ozonation (19\%) and thermal treatment which was least effective ( 5\%) (Salsabil et al., 2010). Yu et al. and Kavitha et al. evaluated the effect of ultrasonication PT of sludge on extraction of extracellular enzymes such as amylase, and protease from sludge. Moreover, no enzyme inactivation was observed during ultrasonication PT (Yu et al., 2008; Kavitha et al., 2016c).

Microwave PT is also a widely used technique for the sludge solubilization (Toreci et al., 2009; Chang et al., 2011; Appels et al., 2013; Kavitha et al., 2016b). Kavitha et al. studied microwave pretreatment and disperser induced microwave pretreatment experiments. Microwave pretreatment of sludge at a specific energy input of $18,000 \mathrm{~kJ} / \mathrm{kg}$ TS achieved a COD solubilization and solids reduction of 16 and $9.3 \%$ respectively. On the other hand, disperser induced microwave pretreatment of sludge at the same energy input increased the COD solubilization and solids reductions to 22 and $17.3 \%$, respectively (Kavitha et al., 2016b). The major pathway for sludge disruption in microwave irradiation technique, can be explained in two ways: (i) the rotation of dipoles under oscillating electromagnetic fields generates a thermal effect, and as a result, intercellular liquor reaches the boiling point which eventually leads to the breakup of bacterial cells and (ii) the changing dipole orientation of polar molecules induces a thermal effect which may break hydrogen bonds and denature biological molecules causing microorganisms to die at lower temperatures (Zhen et al., 2017) (Figure 2). Employing microwave irradiation breaks the hydrogen bonds as the polar side chains of larger molecules combine with the path of the electric field. This method requires high energy consumption and is costly, which can be addressed by combining other treatment methods (Kavitha et al., 2016b).

Thermal disintegration is a promising PT for sludge solubilization. Thermal hydrolysis PT processes employ elevated temperatures and pressures in the presence of water. At these high temperatures and pressures, water is able to cleavage of chemical bonds in complex molecules like sludge and convert them into simpler components (Cheah et al., 2016; Zhen et al., 2017). Şahinkaya and Sevimli (2013) studied the effect of thermal, sonication PT and its combinations, and found that the combined effect of sonic mediated thermal PT achieved a higher degree of COD disintegration (17.8-27\%) than individual PT (Şahinkaya and Sevimli, 2013).

During the hydrodynamic cavitation process, in which high intensity shockwaves are formed, extreme microjets drive the mechanical and chemical effects. Reflection of these effects results in the release of shear forces and decomposition of water molecules to produce $\bullet \mathrm{OH}$, which subsequently breaks the sludge floc and influences sludge disintegration (SeŽun et al., 2019) (Figure 2). Mancuso et al. (2019) concluded that the low-level hydrodynamic cavitation (2 bar) assisted thermalalkaline treatment $\left(50^{\circ} \mathrm{C} \& \mathrm{pH}=10\right)$ was energy efficient and effective in sludge solubilization, which improved the soluble chemical oxygen demand (SCOD) from $118 \mathrm{mg} / \mathrm{L}$ to 10,673 $\mathrm{mg} / \mathrm{L}$. Moreover, the degree of disintegration $\left(\mathrm{DD}_{\mathrm{COD}}\right.$ ) improved to $53 \%$, which was $46.5 \%$ for low level thermal-alkaline and $1.4 \%$ for low level hydrodynamic cavitation, respectively (Mancuso et al., 2019).

Chemical PT involves addition of chemical dosage for enhanced solubilization, floc disruption and effective recovery of biopolymers from sludge. The main reaction that occurred during acidic pretreatment was the hydrolysis of hemicellulose, which broke the cell matrix and released monomeric sugars and oligomers (Zhen et al., 2017) (Figure 2). During alkali $\mathrm{PT}$, an increase in $\mathrm{pH}$ causes a major reaction such as saponification and solvation. Saponification of particulate organics increases COD solubilization, which can be attributed to repulsions between the negatively charged extracellular polymeric substances (EPS). An increase of this electrostatic repulsion increases negatively charged bacterial surfaces, which causes desorption of extracellular polymers (Nazari et al., 2018) and makes them easily accessible to microorganisms.

Xiao et al. (2017) investigated the recovery of protein from sludge by using three PTs such as ultrasonication, thermal and alkali (chemical), and they found that chemical PT at pH 12.0 is very economic and effective in protein solubilization compared to other PTs (Xiao et al., 2017). Various chemicals such as $\mathrm{H}_{2} \mathrm{O}_{2}$, 
TABLE 1 | Summary of key information of sludge pretreatment prior to biological process.

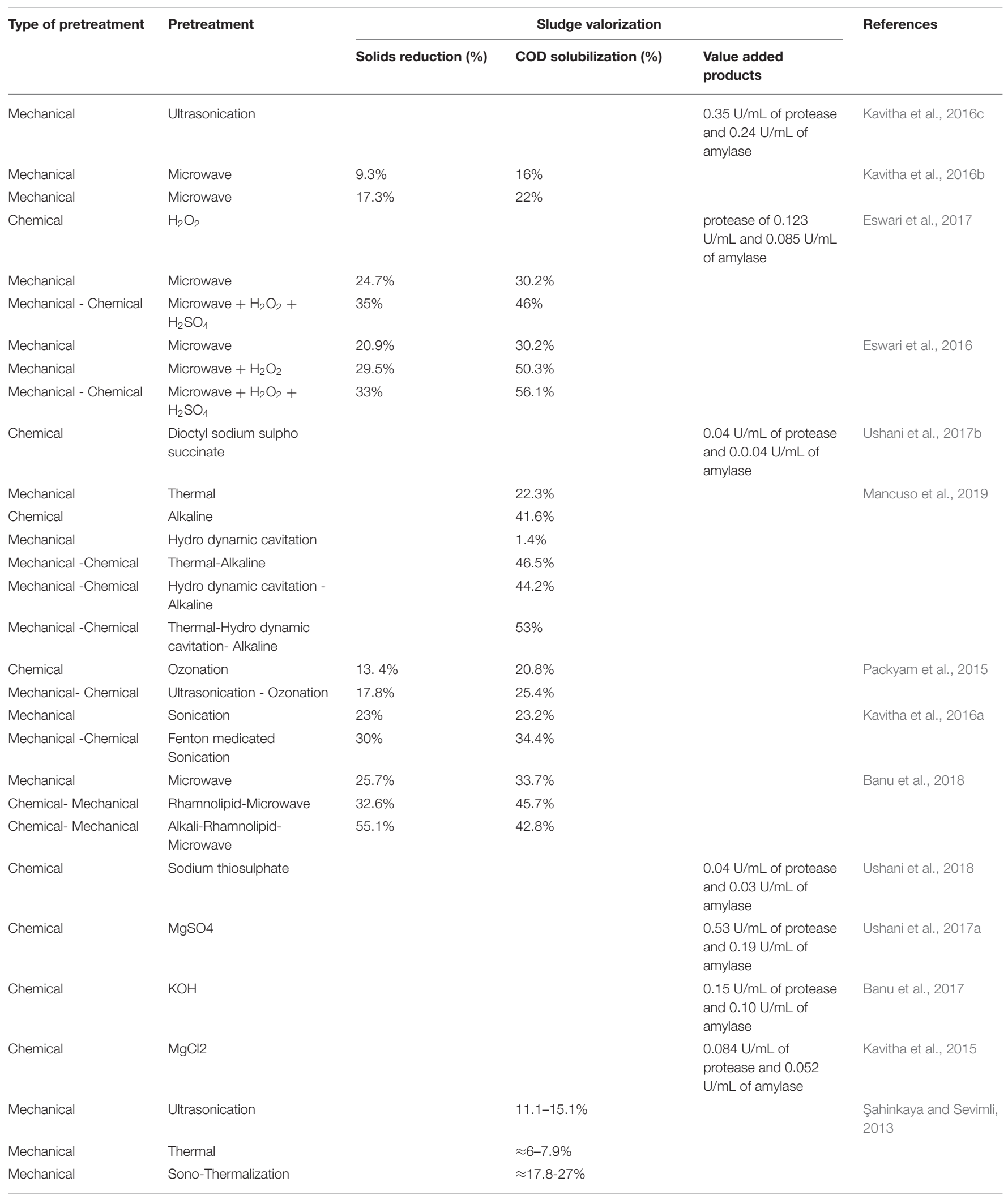


TABLE 1 | Continued

\begin{tabular}{|c|c|c|c|c|c|}
\hline Type of pretreatment & Pretreatment & \multicolumn{3}{|c|}{ Sludge valorization } & References \\
\hline Mechanical & Ultrasonication & $22-31 \%$ & & & Dhar et al., 2012 \\
\hline Mechanical & Thermal & $25-39 \%$ & & & \\
\hline Mechanical & Thermal -sonication & $29-38 \%$ & & & \\
\hline Chemical & Alkaline & & & Protein & \\
\hline Mechanical & Ultrasonication & $47 \%$ & & & Salsabil et al., 2010 \\
\hline Mechanical & Thermal & $5-16 \%$ & & & \\
\hline Mechanical & Ozonation & $19 \%$ & & & \\
\hline Chemical & Potassium ferrate $-\mathrm{NaOH}$ & $8.11 \%$ & & & Li et al., 2019 \\
\hline Mechanical & Microwave & & $8.5 \%$ & & Chang et al., 2011 \\
\hline Chemical & Alkaline & & $18 \%$ & & \\
\hline Mechanical-Chemical & Microwave-Alkaline & & $46 \%$ & & \\
\hline
\end{tabular}

$\mathrm{NaCl}, \mathrm{MgSO}_{4}$, and sodium thiosulphate and were also added to sludge prior to biological processes for protease and amylase extraction (Kavitha et al., 2015; Eswari et al., 2017; Ushani et al., 2017a, 2018) (Table 1).

The combined effects of mechanical and chemical PT of sludge on resource recovery are listed in Table 1. According to the literature, $\mathrm{H}_{2} \mathrm{O}_{2}$ at a dosage of $0.5 \mathrm{mg} / \mathrm{g} \mathrm{SS}$ at $\mathrm{pH} 5.0\left(\mathrm{H}_{2} \mathrm{SO}_{4}\right)$ along with microwave $(10,810 \mathrm{~kJ} / \mathrm{kg}$ TS) PT, improved the SS reduction and COD solubilization to 35 and $46 \%$, respectively (Eswari et al., 2017). Surfactant mediated microwave extraction in alkaline conditions improved the COD solubilization and solid reductions compare to individual PT (Banu et al., 2018). Li et al. (2019) studied the combination of two chemical agents such as potassium ferrate and $\mathrm{NaOH}$ in sludge and observed that volatile suspended solid (VSS) reduction was around $8 \%$. The impacts of ultrasonication of the chemically treated sludge were also examined; mechanical-chemical PT incurred high VSS removal efficiencies ( $13.77 \%$ for $\mathrm{NaOH}+$ ultrasonication; $17.51 \%$ for potassium ferrate + ultrasonication). However, adding ultrasonication to the combination increased costs by 45-66\% (Li et al., 2019) (Table 1).

Whether it was mechanical, chemical, enzymatic or combined $\mathrm{PT}$, sludge disintegration was equally effective, but contaminant removal and VAP production were less effective. Disruption of sludge flocs, effectively released the EPS, however, the macromolecules released along with contaminants were available in the liquid phase, which implies that these components were not removed but readily available for degradation in another manner (Semblante et al., 2015; Rathankumar et al., 2020). So, contaminant removal or resource recovery will be improved when this PT is further accompanied by biological processes.

\section{Pretreatment Assisted Biotechnological Process-Amalgamated Strategy for Resource Recovery and Municipal Solid Waste Stabilization}

The energy recovery outlook implies that anaerobic degradation is the most proficient and economical sludge treatment method (Appels et al., 2008; Nazari et al., 2018) as it produces methane, an energy-rich gas. However, hydrolysis of the organic matter is the rate-limiting step during anaerobic digestion resulting in a long retention time (20-30 days) and lower degradation capacity (30-50\%) (Tyagi and Lo, 2011; Dai et al., 2013). Hence, to aid in the solubilization of organic matter for biodegradation and disintegrating the sludge, several PT methods, such as mechanical, chemical, thermal and biological (Kavitha et al., 2014a) or a combination thereof are required prior to anaerobic treatment. Use of these PT methods accelerates the rate of hydrolysis, and improves the dewaterability of sludge while reducing pathogens (Müller, 2001). PT made substrate more accessible to the indigenous microbial consortium, which accelerated the digestion process as demonstrated by the improved degradation and reduction in sludge volume. PT applied to sludge prior to anaerobic digestion converts harder to degrade complex organic matter into more easily degradable compounds and releases them into the soluble phase. These organic molecules present in the soluble phase are eventually available for biodegradation. Moreover, PT followed by subsequent biological processes achieves improved sludge degradation, enhanced biogas production, VAP extraction, reduced retention time in digesters and lessens the cost of sludge disposal (Kor-Bicakci and Eskicioglu, 2019). The following section discusses the importance of anaerobic/aerobic digestion, 
which is assisted by PT. Moreover, it will show the impact of PT over anaerobic/aerobic digestion on methane production and other VAPs.

\section{Aerobic Digestion}

Three different PTs, ultrasonication, ozonation, and thermal, were used prior to aerobic digestion. Total solid reduction and aerobic biodegradability were monitored to assess the performance of PT (Jaziri et al., 2012). TSS removal improved by 15 and $5 \%$ for ultrasonication and thermal assisted aerobic digestion. On the other hand, no TSS removal was obtained with ozonation PT assisted aerobic digestion. This might be explained by the release of radical scavengers, which are inefficient at materializing the sludge because of high ozone dosage ( $>0.1 \mathrm{~g} \mathrm{O} / \mathrm{g}$ TS). Aerobic biodegradability can be expressed by three factors i) global $\mathrm{CO}_{2}$ production ii) maximum specific $\mathrm{CO}_{2}$ production rate and iii) initial $\mathrm{CO}_{2}$ production rate. The global $\mathrm{CO}_{2}$ production, initial $\mathrm{CO}_{2}$ production rate and maximum specific $\mathrm{CO}_{2}$ production rate improved to 19,11 , and $3.4 \%$ respectively for thermal assisted aerobic processes, nil, 2 and $30.3 \%$ respectively, for ultrasonication assisted aerobic processes and 5, 10, and 20\% respectively, for ozonation assisted aerobic processes. Based on the global $\mathrm{CO}_{2}$ production, sludge degradability improved for thermal and ozonation PT. But, no real improvement in biodegradability was observed for sonication assisted aerobic digestion (Jaziri et al., 2012). Combining microwave and alkali PTs improves the rate of solubilization while reducing the energy consumption and reaction time when compared to microwave or alkali PT alone. A $63 \%$ reduction of VSS was observed for aerobic digestion of sludge by integrated microwave and alkali PT (Chang et al., 2011).

Wang et al. (2018) studied free ammonia PT with subsequent aerobic digestion for 15 days, which resulted in a 36\% volatile solid reduction with improved biodegradability. Degradation in the first 6 days of the 15 days of the aerobic digestion was faster since it occurred in the more easily biodegradable molecules first. After 6 days, the degradation was slow, and it becomes stabilized. However, PT becomes practically feasible when sludge disposal and transportation costs are higher than US $\$ 40 /$ ton of dried sludge (Wang et al., 2018). Ultrasonication, ozonation and thermal PT with subsequent aerobic and anaerobic digestion were tested separately, and ultrasonication or ozonation PT assisted biological processes were found to be energy efficient and cost effective. PT of anaerobic waste resulted in higher total suspended solids (TSS) reduction in contrast to aerobic waste, implying that anaerobic treatment is effective when compared to aerobic treatment during sludge reduction (Salsabil et al., 2010).

A degradation study on diclofenac was carried out on digested dewatered sewage sludge. During this study (Haiba et al., 2017), anaerobic digested sludge was mixed with sawdust in two different ratios of 1:2 and 1:3, followed by aerobic composting. Over $95 \%$ removal of diclofenac was observed in both compost mixtures. However, the PhAC degradation was comparatively higher in the 1:3 compost mixture (Haiba et al., 2017). Ten different commonly occurring PhACs and their degradation by composting of sludge with enrichment (rice straw) were analyzed. Reduction due to composting (C/N:20) occurred for azithromycin (upto 50\%), irbesartan, fluoxetine (100\%), and citalopram (15\%) but telmisartan and venlafaxine showed no signs of degradation. Composting with five different $\mathrm{C} / \mathrm{N}$ ratio blends (C/N:17; C/N:20; C/N:24; C/N:29; C/N:37) for PhACs removal were also examined. Five out of $10 \mathrm{PhACs}$, azithromycin, ibuprofen, irbesartan, olanzapine, and benzylpenicillin, were reduced in all the composting studies. Degradation pathway for benzylpenicillin, a $\beta$-lactam antibiotics was hydrolytic cleavage of beta-lactam ring followed by decarboxylation step. $\beta$-lactamase enzyme is responsible for the hydrolytic cleavage of beta-lactam ring and presence of these enzymes are responsible for the degradation of benzylpenicillin all composting samples (Dantas et al., 2008; Gatica and Cytryn, 2013). However, telmisartan was only reduced in $\mathrm{C} / \mathrm{N}: 37$ and fluoxetine, venlafaxine, and citalopram were only reduced in C/N:20. The trend shows that the degradation effect of PhACs depends on different composting blends with different half-life periods. Microorganisms use azithromycin and ibuprofen as carbon sources and irbesartan as a sole nitrogen source during degradation and composting (Iranzo et al., 2018) (Table 2). PhACs concentrations in dehydrated sludge were reduced more in anaerobic digestion than in aerobic digestion (Martín et al., 2015). Biodegradation followed by irreversible radiation and volatilization alleviated pharmaceutical removal for aerobic treatment (Wang et al., 2019).

\section{Anaerobic Digestion}

Thermal PT has also been extensively studied for the temperature range from $60-270^{\circ} \mathrm{C}$ (Climent et al., 2007). Thermalization at low temperatures enhances the methane production and removal of organic matter. The combination of sonication and thermalization, known as "sono-thermalization," uses the temperature rise during sonication for subsequent low temperature thermalization (Şahinkaya and Sevimli, 2013). This combined treatment method significantly improved the reduction of organic matter and production of methane when digested anaerobically. The increase in methane and biogas production by sono-thermalization were found to be 13.6 and $14 \%$ respectively, as reported by Şahinkaya and Sevimli (2013). This method was not, however, economically feasible due to its high energy requirements. In decreasing order, the disintegration efficiencies were sono-thermalization, sonication, and thermalization (Şahinkaya and Sevimli, 2013). Dispersion induced microwave PT followed by anaerobic digestion were also investigated, and floc dispersion of biomass was highly effective at $25.3 \mathrm{~kJ} / \mathrm{kg}$ TS. Whereas, at a specific energy of $18 \mathrm{~kJ} / \mathrm{kg}$ TS, COD solubilization, SS reduction and volatile fatty acid (VFA) production were $17.3 \%, 22 \%$, and $770 \mathrm{mg} / \mathrm{l}$, respectively (Table 2). However, based on the economic analysis, the disperser induced microwave treatment with subsequent anaerobic digestion was found to be profitable (US\$104.8/ton of sludge) (Kavitha et al., 2016b) (Table 2).

Banu et al. (2018) studied the impact of microwave PT, surfactant assisted microwave PT and surfactant assisted microwave PT at alkaline conditions followed by anaerobic digestion for sludge solubilization, and biogas production. COD liquefaction was $33.7 \%$ for microwave PT at a specific energy 
TABLE 2 | Summary of key information of sludge pretreatment assisted biological process.

\begin{tabular}{lllll}
\hline $\begin{array}{l}\text { Type of } \\
\text { pretreatment }\end{array}$ & \multicolumn{3}{c}{ Sludge valorization } & Remarks \\
\cline { 2 - 4 } & $\begin{array}{l}\text { Solids } \\
\text { reduction } \\
(\%)\end{array}$ & $\begin{array}{l}\text { COD } \\
\text { solubilization } \\
(\%)\end{array}$ & $\begin{array}{l}\text { Contaminants } \\
\text { removal }(\%)\end{array}$ & Value added products \\
& & & \\
\end{tabular}

\section{Anaerobic Digestion}

Microwave

$9.3 \%$

$16 \%$

$\begin{array}{lll}\begin{array}{l}\text { Disperser } \\ \text { induced }\end{array} & 17.3 \% & 22 \% \\ \text { Microwave } & & \\ \text { Microwave } & 24.7 \% & 30.2 \%\end{array}$

Microwave +
$\mathrm{H}_{2} \mathrm{O}_{2}+\mathrm{H}_{2} \mathrm{SO}_{4}$

Microwave

$35 \%$

$46 \%$

$20.9 \%$

$30.2 \%$

$\begin{array}{lll}\text { Microwave }+ & 29.5 \% & 50.3 \% \\ \mathrm{H}_{2} \mathrm{O}_{2} & & \\ \begin{array}{l}\text { Microwave }+ \\ \mathrm{H}_{2} \mathrm{O}_{2}+\mathrm{H}_{2} \mathrm{SO}_{4}\end{array} & 33 \% & 56.1 \% \\ \text { Ozonation } & 13.4 \% & 20.8 \%\end{array}$

Ultrasonication- $\quad 17.8 \% \quad 25.4 \%$

Ozonation

$62 \% \quad 60.6 \%$

Sonication

$23 \%$
Volatile fatty acids

(VFA)production $\approx 500 \mathrm{mg} / \mathrm{L}$

Net profit of 104.8 USD/ton of

Kavitha et al., 2016a

sludge was obtained for disperser induced microwave which was negative net cost (15.9 USD/ton of sludge) for microwave pretreatments

Volatile fatty acids (VFA) production $\approx 770 \mathrm{mg} / \mathrm{L}$

Methane yield-150 mL/g VS

Compared to individual pretreatment $(-10.2 €$ per ton of sludge), combined effect of mechanical-chemical pretreatment earned a net profit of ( $49 €$ per ton of sludge)

Methane yield-250 mL/g VS

$\mathrm{IBP}^{\mathrm{a}}, \mathrm{CBZ}^{\mathrm{b}}$, and $\mathrm{DZ} \mathrm{P}^{\mathrm{c}}$ removal of (25-50\%) $\mathrm{SMX}^{\mathrm{d}}, \mathrm{ROX}^{\mathrm{e}}$ and NPX removal of (75-100\%)
VFA production $\approx 730 \mathrm{mg} / \mathrm{L}$ and Methane yield-175 $\mathrm{mL} / \mathrm{g}$ VS

VFA production $\approx 1,950$ $\mathrm{mg} / \mathrm{L}$ and Methane yield$288 \mathrm{~mL} / \mathrm{g}$ VS

VFA production $\approx 2,050$ $\mathrm{mg} / \mathrm{L}$ and Methane yield-323 $\mathrm{mL} / \mathrm{g}$ VS

Biogas production $=0.535$ L/g VS

Both combined effect Mechanical- chemical more than individual mechanical pre-treatment.

However, combined pre-treatment in the presence of acidic conditions ( $\mathrm{MW}+\mathrm{H}_{2} \mathrm{O}_{2}+$ $\mathrm{H}_{2} \mathrm{SO}_{4}$ ) will be more profitable (59.9 € sludge) when compared with $\left(\mathrm{MW}+\mathrm{H}_{2} \mathrm{O}_{2}\right)$, which was 30.5 per ton of sludge

Both combined and individual pretreatments, were incurred a negative net profit of $-4.21 € /$ ton of sludge and $-5.27 € /$ ton of sludge, respectively and found not profitably feasible for field applications.

Biogas production $=0.637$ L/g VS

$1.05 \mathrm{~L} / \mathrm{L}$ d of biogas production

maximum methane production potential $=0.2 \mathrm{~g}$ COD/g COD pre-treatments earned net profit
Packyam et al., 2015

Gonzalez-Gil et al., 2016

Kavitha et al., 2016a
No mutagenetic activity and estrogenic activity decreases after $A D$

Net profit of 44.9 USD/ton of sludge was obtained for fenton mediated sonication which was negative net cost (-87.7 USD/ton of sludge) for sonication pretreatments. 
TABLE 2 | Continued

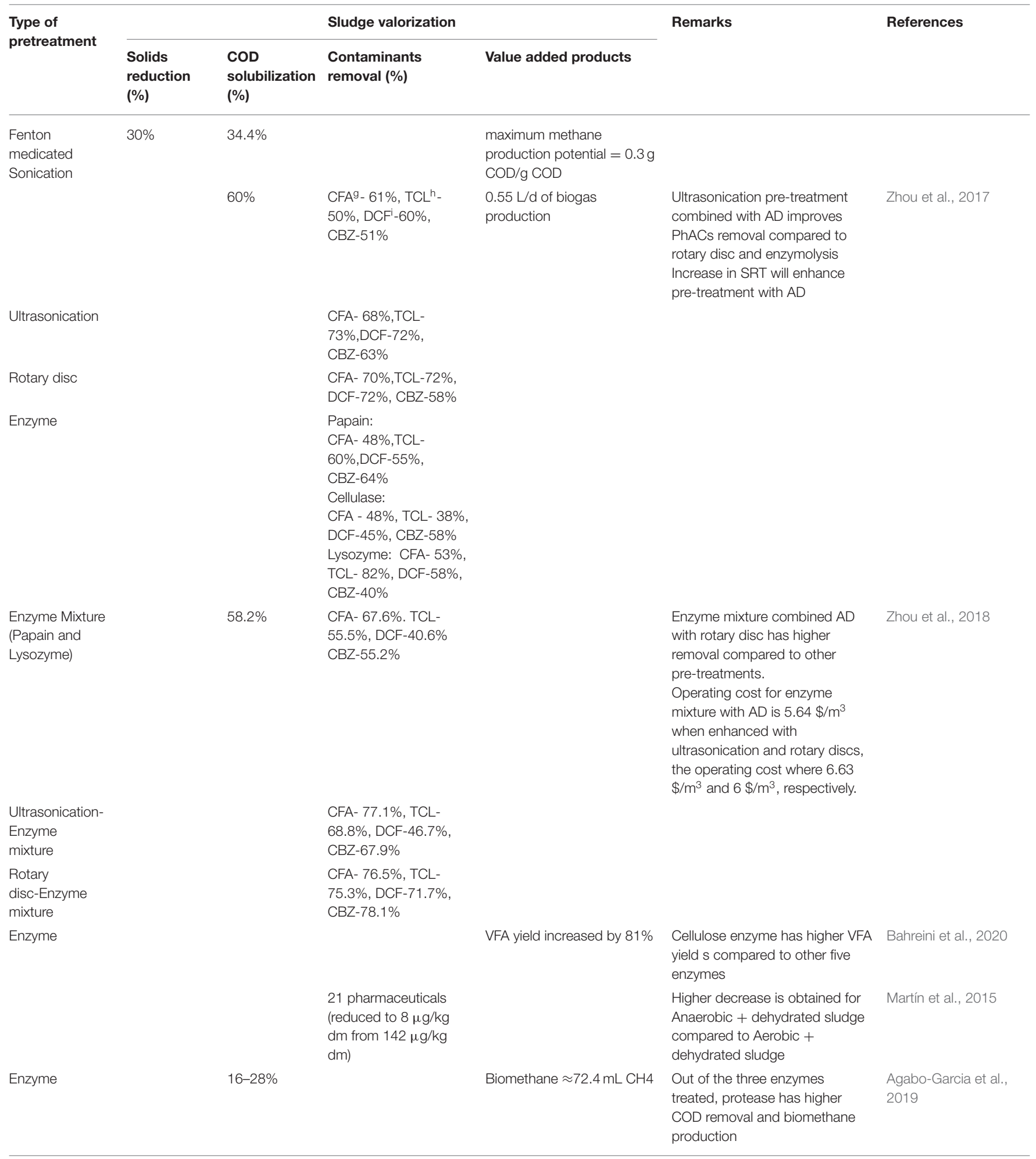


TABLE 2 | Continued

\begin{tabular}{|c|c|c|c|c|c|c|}
\hline $\begin{array}{l}\text { Type of } \\
\text { pretreatment }\end{array}$ & \multicolumn{4}{|c|}{ Sludge valorization } & Remarks & References \\
\hline Ultrasonication & & & & $\begin{array}{l}\text { Methane yield of } 0.17 \mathrm{~m}^{3} \\
\mathrm{CH}_{4} / \mathrm{kg} \text { COD removed. }\end{array}$ & $\begin{array}{l}\text { All disintegration methods were } \\
\text { incurred negative cost, and for } \\
\text { economic feasibility ranking in } \\
\text { the order of } \\
\text { ultra-sonication(- }-473 € / \text { t of } \\
\text { sludge }>\text { Microwave ( }-512 € / t \\
\text { of sludge) }>\text { enzyme mixture } \\
\text { (-8983 €/t of sludg) }\end{array}$ & Tas et al., 2018 \\
\hline Enzyme & & & & $\begin{array}{l}\text { Methane yield of } 0.17 \mathrm{~m}^{3} \\
\mathrm{CH}_{4} / \mathrm{kg} \text { COD removed. }\end{array}$ & & \\
\hline Microwave & & & & $\begin{array}{l}\text { methane yield of } 0.22 \mathrm{~m}^{3} \\
\mathrm{CH}_{4} / \mathrm{kg} \text { COD removed }\end{array}$ & & \\
\hline Thermal & $69-76 \%$ & & & & & \\
\hline Ozonation & $78 \%$ & & & & & \\
\hline Microwave & $24.6 \%$ & $33.7 \%$ & & $\begin{array}{l}\text { Biomethane production of } \\
239 \mathrm{~mL} / \mathrm{g} \text { COD }\end{array}$ & $\begin{array}{l}\text { Rhamnolipid mediated } \\
\text { microwave disintegration in the } \\
\text { presence of alkaline environment } \\
\text { earned a net profit ( } 0.39 \$ / \text { ton of } \\
\text { sludge) and is highly profitable } \\
\text { when compared with rhamnolipid } \\
\text { mediated microwave and } \\
\text { microwave pretreatment which } \\
\text { was }-31.3 \$ / t \text { of sludge and } \\
-84.2 \$ / t \text { of sludge, respectively. }\end{array}$ & Banu et al., 2018 \\
\hline Thermal & $31.1 \%$ & $\approx 6-7.9 \%$ & & $\begin{array}{l}\text { Increase in methane and } \\
\text { biogas production were } \\
4.2 \% \text { and } 3.5 \% \text {, } \\
\text { respectively. }\end{array}$ & & \\
\hline $\begin{array}{l}\text { Sono- } \\
\text { Thermalization }\end{array}$ & $37.8 \%$ & $\approx 17.8-27 \%$ & & $\begin{array}{l}\text { Increase in methane and } \\
\text { biogas production were } \\
13.6 \text { and } 14 \% \text {, respectively }\end{array}$ & & \\
\hline Ultrasonication & $22-31 \%$ & & & $\begin{array}{l}15-24 \% \text { increase in } \\
\text { methane production }\end{array}$ & $\begin{array}{l}\text { Most cost effective pretreatment } \\
\text { is a combination of thermal at } \\
90^{\circ} \mathrm{C}+\text { ultrasound at } \\
1,000 \mathrm{~kJ} / \mathrm{kg} \text { TSS } \approx 44 \$ / \mathrm{t} \text { of dry } \\
\text { sod }\end{array}$ & Dhar et al., 2012 \\
\hline Thermal & $25-39 \%$ & & & $\begin{array}{l}13-19 \% \text { increase in } \\
\text { methane production }\end{array}$ & & \\
\hline $\begin{array}{l}\text { Thermal- } \\
\text { Ultrasonication }\end{array}$ & $29-38 \%$ & & & $\begin{array}{l}19-30 \% \text { increase in } \\
\text { methane production }\end{array}$ & & \\
\hline
\end{tabular}


TABLE 2 | Continued

\begin{tabular}{|c|c|c|c|c|c|c|}
\hline $\begin{array}{l}\text { Type of } \\
\text { pretreatment }\end{array}$ & \multicolumn{4}{|c|}{ Sludge valorization } & Remarks & References \\
\hline Hydrocyclone & 23.4 & & & $\begin{array}{l}\text { Methane production of } 101 \\
\mathrm{~mL} / \mathrm{g}\end{array}$ & $\begin{array}{l}\text { Most cost effective pre-treatment } \\
\text { is Hydro cyclone mediated } \\
\text { alkaline with net profit of } \\
68.57 \$ / \text { to f sludge compared to } \\
\text { individual hydro cyclone } \\
\text { pre-treatment ( } 13.42 \$ / \mathrm{t} \\
\text { of sludge) }\end{array}$ & Sun et al., 2019 \\
\hline $\begin{array}{l}\text { Hydrocyclone- } \\
\text { alkaline }\end{array}$ & $29.3 \%$ & & & $\begin{array}{l}\text { Methane production of } \\
134.2 \mathrm{~mL} / \mathrm{g}\end{array}$ & & \\
\hline \multicolumn{7}{|c|}{ Aerobic digestion } \\
\hline Thermal & $62-68 \%$ & & & & & \\
\hline Ozonation & $71 \%$ & & & & & \\
\hline Ultrasonication & $36 \%$ & & & & $\begin{array}{l}\text { Pretreatment with ultrasonication } \\
\text { increases the sludge resistance } \\
\text { to dewatering }\end{array}$ & Erden et al., 2010 \\
\hline Ozonation & $34.1 \%$ & & & & & \\
\hline Free ammonia & $36 \pm 4 \%$ & & & & $\begin{array}{l}\text { Sludge disposal and } \\
\text { transportation cost is higher than } \\
\$ 40 / \text { wet ton, free ammonia } \\
\text { pretreatment will be } \\
\text { economically feasible. }\end{array}$ & Wang et al., 2018 \\
\hline Thermal & $5 \%$ & & & $\begin{array}{l}\text { Biogas production improved } \\
\text { by } 19 \%\end{array}$ & $\begin{array}{l}\text { Aerobic digestion followed by } \\
\text { thermal pretreatment improved } \\
\text { sludge reduction and } \\
\text { biodegradability compared to } \\
\text { other two treatments. }\end{array}$ & Jaziri et al., 2012 \\
\hline & & & $\begin{array}{l}\text { Pharmaceuticals } \\
(42-100 \%)\end{array}$ & No laccase activity & $\begin{array}{l}\text { Compared with autochthons } \\
\text { microbiome, sludge } \\
\text { bioaugmented with Trametes } \\
\text { versicolor has higher removal of } \\
\text { PhACs }\end{array}$ & $\begin{array}{l}\text { Rodríguez-Rodríguez } \\
\text { et al., } 2012\end{array}$ \\
\hline & & & $\begin{array}{l}21 \text { pharmaceuticals } \\
\text { (reduced to } 70 \mu \mathrm{g} / \mathrm{kg} \\
\mathrm{dm} \text { from } 142 \mu \mathrm{g} / \mathrm{kg} \\
\mathrm{dm} \text { ) }\end{array}$ & & $\begin{array}{l}\text { Lower decrease is obtained for } \\
\text { Aerobic + dehydrated sludge } \\
\text { compared to Anaerobic }+ \\
\text { dehydrated sludge }\end{array}$ & Martín et al., 2015 \\
\hline & & $19.87 \%$ & $\begin{array}{l}89.6-95.4 \% \text { of norflaxin } \\
\text { and } 87.2-95.4 \% \text { of } \\
\text { ofloxacin }\end{array}$ & & $\begin{array}{l}\text { Biodegradation is the major } \\
\text { pathway for PhACs removal } \\
\text { which was followed by } \\
\text { irreversible radiation and } \\
\text { volatilization }\end{array}$ & Zhang et al., 2019 \\
\hline & & & $\begin{array}{l}\text { 95\% degradation of } \\
\text { diclofenac }\end{array}$ & & $\begin{array}{l}1: 3 \text { ratio of sewage sludge and } \\
\text { sawdust has higher removal } \\
\text { compared to } 1: 1 \text { ratio }\end{array}$ & Haiba et al., 2017 \\
\hline
\end{tabular}


TABLE 2 | Continued

\begin{tabular}{|c|c|c|c|c|c|c|}
\hline \multirow{2}{*}{$\begin{array}{l}\text { Type of } \\
\text { pretreatment }\end{array}$} & \multicolumn{4}{|c|}{ Sludge valorization } & \multirow[t]{2}{*}{ Remarks } & \multirow[t]{2}{*}{ References } \\
\hline & $\begin{array}{l}\text { Solids } \\
\text { reduction } \\
\text { (\%) }\end{array}$ & $\begin{array}{l}\text { COD } \\
\text { solubilization } \\
(\%)\end{array}$ & $\begin{array}{l}\text { Contaminants } \\
\text { removal (\%) }\end{array}$ & Value added products & & \\
\hline \multirow[t]{3}{*}{$\begin{array}{l}\text { Microwave- } \\
\text { alkali }\end{array}$} & $63 \%$ & & & & $\begin{array}{l}\text { Combined pretreatment } \\
\text { improves solubilization rate, } \\
\text { reduces energy consumption } \\
\text { and reaction time compared to } \\
\text { the individual pretreatments }\end{array}$ & Chang et al., 2011 \\
\hline & & & $\begin{array}{l}\text { Reduction in } \\
\text { fluoroquinolones and } \\
\text { sulfonamides }\end{array}$ & & $\begin{array}{l}\text { Reduction was due to anaerobic } \\
\text { digestion before composting }\end{array}$ & Lillenberg et al., 2010 \\
\hline & & & Metformin-90\% & & $\begin{array}{l}\text { No removal occurred for } \\
\text { carbamazepine during, } \\
\text { composting so different meant of } \\
\text { studies will be required }\end{array}$ & Haiba et al., 2018 \\
\hline
\end{tabular}

albuprofen.

${ }^{b}$ Carbamazepine.

cDiazepam.

${ }^{d}$ Sulfamethoxazole.

${ }^{e}$ Roxithromycin.

${ }^{f}$ Naproxen.

${ }^{g}$ Clofibiric acid.

${ }^{n}$ Triclosan.

'Diclofenac.

of $6,480 \mathrm{~kJ} / \mathrm{kg}$ TS, while the addition of surfactant (dosage of $0.003 \mathrm{~g} / \mathrm{g}$ of SS) along with microwave PT (specific energy of $3,240 \mathrm{~kJ} / \mathrm{kg}$ TS) increased liquefaction to $45.7 \%$. Whereas, at alkaline mediated surfactant assisted microwave PT, COD liquefaction increased to 55\%. Adding alkaline and surfactant slightly reduces the microwave energy to help achieve maximum COD solubilization. The biomethane production was $379 \mathrm{~mL} / \mathrm{g}$ COD for alkaline mediated chemo-mechanical PT, which was $329 \mathrm{~mL} / \mathrm{g}$ COD and $239 \mathrm{~mL} / \mathrm{g}$ COD for surfactant assisted microwave and microwave PT, respectively (Banu et al., 2018). Fenton assisted sonication is also extensively used for sludge disintegration as it effectively cleaves the cell walls of sludge biomass through an oxidation-reduction reaction. The Fenton oxidation process is a promising technique for sludge reduction and biogas production enhancement. The principle behind this oxidation process involves the reaction of hydrogen peroxide with iron ions to produce highly active hydroxy radicals, which are effective in the disruption of EPS and in cell lysis of microorganisms (Zhen et al., 2017). Kavitha et al. showed that Fenton mediated sonication gave a maximum methane production potential of $0.3 \mathrm{~g}$ CODg COD (Kavitha et al., 2016a). Packyam et al. (2015) investigated the effect of ozonation and sono-ozonation over biogas production. In these anaerobic digestion study, sonication was introduced for sludge deflocculation, while ozonation used for cell disintegration. And showed that biogas production from flocculated sludge (ozone pretreated alone) was $931 \mathrm{~mL}$ with a maximum biogas production rate of $4.0697 \mathrm{~L} / \mathrm{g} \mathrm{VS} \mathrm{d}$. On the other hand, sludge which was first deflocculated by sonication (Specific energy dosage of $76.4 \mathrm{~kJ} / \mathrm{kg}$ TS), and then subsequently followed by cell disintegration by ozone (ozone dosage of $0.0011 \mathrm{mg} \mathrm{O} / \mathrm{mg} \mathrm{SS}$ ) PT improved the biogas production to $1,123 \mathrm{~mL}$ with a maximum biogas production rate of $5.2041 \mathrm{~L} / \mathrm{g}$ VS d. Improved biogas production was due to the release of SCOD during sonication and the release of particulate organic matter through cell lysis of ozone treatment prior to the bioprocess. This proved that ozone given in low doses at lower ultrasonic specific energy enhances anaerobic biodegradability (Packyam et al., 2015).

Alkaline mediated surfactant assisted microwave PT with subsequent anaerobic digestion earned a very meager net profit of US\$0.39/ton of dried sludge but both microwave and surfactant assisted microwave PT were not feasible for operation because of negative net profits (-US\$84.2/ton of dried sludge and -US\$31.3/ton of dried sludge, respectively; Banu et al., 2018) (Table 2). Even with improved biogas production and effective COD solubilization, the PT assisted anaerobic digestion was economically unfeasible because of negative net profits (Şahinkaya and Sevimli, 2013). Tas et al. (2018), however, felt that economic cost assessments carried under laboratory conditions were not enough to judge if this technique was applicable for full scale operation (Tas et al., 2018).

Zhou et al. (2018) investigated the effect of an enzyme mixture combined with ultrasonication and a rotatory disc on the removal of four PhACs. The rotatory disc combined with enzyme treatment resulted in efficient removal (clofibiric acid- $76.5 \%$, triclosan - 75.3\%, diclofenac - 71.7\%, carbamazepine - 78.1\%) compared with an ultrasonication combination or individual enzyme mixture. Operating costs, however, increased with combined PTs (ultrasonication \& enzyme mixture $-6.63 \$ / \mathrm{m}^{3}$ and rotatory disc \& enzyme mixture - $6 \$ / \mathrm{m}^{3}$ ) which was 
only $5.64 \$ / \mathrm{m}^{3}$ for an individual enzyme mixture (Zhou et al., 2018). The occurrence and removal of organic micropollutants during anaerobic digestion was studied, and high concentrations of ibuprofen, triclosan, and musk fragrances were found in the analyzed sludge. After biological processes, the removal of sulfamethazine, roxithromycin, naproxen was around 75$100 \%$ and diazepam, carbamazepine, ibuprofen removal was around $25-50 \%$. In addition, a $60 \%$ COD removal and a biogas production of $1.05 \mathrm{~L} / \mathrm{L} \mathrm{d}$ were observed. Moreover, biological assays were performed (Ames and Comet test) on digested sludge to verify its adverse effects on environment and human health, with Ames test it confirmed that there no changes in mutagenic activity after anaerobic digestion. However, with Comet test the presence of genotoxic effect in digested sludge was confirmed (Gonzalez-Gil et al., 2016) (Table 2).

In most of the cases, combined PT followed by anaerobic digestion improved methane production, solid reduction, sludge solubilization and contaminant removal. Moreover, they could be cost effective compared to individual PT with subsequent biological processing (Packyam et al., 2015; Kavitha et al., 2016b; Eswari et al., 2017; Zhou et al., 2017, 2018; Banu et al., 2018; Ushani et al., 2018; Sun et al., 2019) (Table 2). On the other hand, implementation of pre-treatment prior to biological processing requires enormous amount of energy and additional space for installation (for physical pretreatment), corrosive effects and difficulties in balancing $\mathrm{pH}$ (chemical pretreatment), installation costs and maintaining optimal condition for microbial activities (biological pretreatment) are the major constraints limits those applications on an industrial scale (Nguyen et al., 2021).

\section{Bioaugmentation-A Reinvigorating Approach to Pretreatment Enhanced Digestion for Municipal Solid Waste Valorization}

Environmentally friendly approaches such as adding enzyme secreting bacteria (bioaugmentation) and/or pretreating with enzymes (biostimulation) have the potential to reduce the volume of sludge and simultaneously remove pollutants contained in it (Barnabé et al., 2009; Semblante et al., 2015; Seo et al., 2017). The global market for waste management was valued at around US $\$ 2080$ billion in 2019, with an estimated compound annual growth rate (CAGR) of 5.5\% between 2020 and 2027 and is expected to reach US $\$ 2339.8$ billion by 2027 (Allied Market Research, 2018), with bioaugmentation representing about a ninth of it. Bioaugmentation is a technique to increase the rate of bioremediation by taking advantage of the synergistic effect among organisms. A successful bioremediation process usually involves the use of approaches tailored for the specific environmental conditions at the site. The need for bioaugmentation arises when the indigenous organisms are slow/unable to biodegrade the contaminants in the sludge. The introduction of new strains improves the performance of the existing strains while simultaneously boosting contaminant removal. In addition, if appropriate formulations are applied, the sludge microbial mixture can be used as microbial inoculants or biopesticides for agricultural land (Barnabé et al., 2009; Cao et al., 2020). However, the major setback associated with this biological approach is time consumption and proper selection of microorganisms/enzymes. Inaccessibility of substrate, where the polymeric substances immobilized within sludge floc make things difficult for bioaugmented strain/indigenous microbes, could be the cause of this time consumption. The rate-limiting step of hydrolysis can be avoided by introducing PT prior to bioaugmentation. Mechanical, chemical or their combinational PTs are well-known for their merits such as odorless sludge, extraction of VAPs and the removal of pollutants. However, the major demerits are environmental pollution due to chemical agents, economic constraints and operational feasibility (Yu et al., 2013; Semblante et al., 2015; Seo et al., 2017; Rathankumar et al., 2020). So, the next part of this section focuses on the impact of introducing PT to bioaugmentation and its potentially prolonged effect on the system. In addition, it provides an overview of which PT are suitable for aerobic/anaerobic digestion and how it is effective over VAP production and its associated costs.

While the bioaugmentation technique is theoretically feasible, in practice, there are numerous obstacles such as the availability of substrate, competition between microbes, preference of organic substrates over pollutants, and predation (Goldstein et al., 1985). The abiotic stresses that suppress microbial growth include water content, temperature, nutrient depletion, $\mathrm{pH}$, and potentially toxic pollutant levels in the sludge (Gentry et al., 2004; Roy et al., 2018). These constraints in addition to insufficient published literature have a negative effect on the trials and laboratory experiments. Some of the key factors of this negative effect are microbial selection, fermentation environment, contaminant type, abiotic parameters, and issues related to introduction (Tyagi and Lo, 2011). The microbial selection is usually done by adding a microbial strain, microbial consortium or by introducing pre-adapted genetically engineered microorganisms.

Despite the challenges mentioned above, bioaugmentation has shown various applications in soil remediation (Cycoń et al., 2017), oil spills (Roy et al., 2018), WWTPs (Raper et al., 2018) and ground water dechlorination (Chang et al., 2021; Li et al., 2021). Most of the reviews about bioaugmentation in soil remediation during the late twentieth century were of a cautionary tale (Vogel, 1996). This was mainly due to the insufficient literature and inadequate lab-scale experiments. Moreover, resource recovery was not considered, and contaminant removal was low. However, this has changed over the years and increasing information about the interaction of organisms and genetic predisposition has led to a tremendous increase in scope (Sharma and Jain, 2020). The use of bioaugmentation over other methods is attributed to its productivity and cost-effectiveness (GarciaBlanco et al., 2007). Specifically, PAHs can be metabolized by a consortium of bacteria, which protects the environment by avoiding leaching of these contaminants into groundwater. In areas where groundwater is contaminated by chlorinated ethenes (Lendvay et al., 2003), bioaugmentation ensures that the in situ microorganisms completely degrade the chemicals to chlorine and ethylene (Yang et al., 2019). Typically, it is used only in the bioremediation of chlorinated ethenes although research is 
being done in compounds like chloroethanes (Li et al., 2021) chloromethanes and methyl t-butyl ether (MtBE) (d'Errico et al., 2020).

Valorization of sludge in bioaugmentation has three main criteria. First, the massive volume of sludge is a key criterion when biodegradation of waste is concerned. Thus, volume reduction is essential for proper disposal of the waste. Second, toxic by-products in waste-generating plants could lead to bioaccumulation. The waste should therefore be devoid of toxic contaminants before disposal (Appels et al., 2013). Finally, microbial activity may lead to the formation of VAP, like surface active compounds, bioactive compounds, phytochemicals and dietary fibers (Kumar et al., 2021). This "resource recovery" helps in the circular economy, and hence, forms an essential part of waste valorization. In addition, the cost and energy consumption of the methods play a major role during their use in large volume bioreactors (Lipińska et al., 2021).

Various microbes have been used in bioaugmentation like Bacillus spp. (Kavitha et al., 2013, 2016c; Ushani et al., 2017c), Trametes versicolor (Rodríguez-Rodríguez et al., 2012, 2014; Llorens-Blanch et al., 2018), Bjerkandera adusta (Aydin, 2016), Bacillus licheniformis (Merrylin et al., 2014a), B. thuringiensis (Vidyarthi et al., 2002; Pham et al., 2010; Cerda et al., 2019; Rodríguez et al., 2019) and Exiguobacterium sp. (Banu et al., 2017) (Table 3). A major factor to be considered before bioaugmentation is the type of fermentation. The VAP to be obtained depends greatly on the organism and its metabolism. Augmenting aerobic organisms during anaerobic fermentation will result in failure and vice-versa. Additionally, aerobic, and anaerobic fermentation have different effects on waste, especially activated sludge. This is evident in the work done by Kavitha et al. (2013, 2014a, 2015, 2016c) where they bioaugmented Bacillus jerish 03 and B jerish 04 in both aerobic and anaerobic conditions. This served as an appropriate barometer to compare the two types of fermentation.

\section{Aerobic Digestion}

The sludge was treated under aerobic conditions by bioaugmenting $B$. jerish 03 and B. jerish 04 which were previously assisted by either ultrasonication or ethylene diamine tetra acetic acid (EDTA) for EPS release (Kavitha et al., 2013, 2016c). The reduction in SS, and COD solubilization were evaluated to consider the effect of the volume reduction and biodegradability of the sludge. Furthermore, VAPs, like protease and amylase, were quantified. To evaluate the importance of ultrasonication PT, ultrasonication assisted bioaugmentation, and bioaugmentation without ultrasonication were performed (Kavitha et al., 2016c). The complex nature of the flocs and immobilization of the enzymes inside the flocs restricted the disintegration potential in the bioaugmentation without ultrasonication, which had a $15 \% \mathrm{SS}$ reduction after $56 \mathrm{~h}$. On the other hand, SS reduction in PT assisted bioaugmentation was about 21\%; floc disruption during ultrasonication had helped the bacterial consortium along with bioaugmented bacteria to achieve improved SS reduction. The energy consumption and associated costs were calculated to determine the proficiency of the method. PT assisted bioaugmentation consumed $160.8 \mathrm{kWh}$ of energy and earned a net profit of US\$27/ton of dried sludge, compared to $160.2 \mathrm{kWh}$ and a negative net gain (-US\$6/ton of dried sludge) bioaugmentation without PT (Kavitha et al., 2016c). The impact of adding EDTA prior to bioaugmentation of $B$. jerish 03 and B. jerish 04 for the degradation process was studied by Kavitha et al. (2013). SS reduction for EDTA-assisted bioaugmentation was 24 vs. $15.7 \%$ for bioaugmentation without EDTA addition. Enhanced 8.3\% removal for EDTA-assisted bioaugmentation was supported by combined enzyme activity (enzymes secreted by facultative anaerobes along with extraction of enzymes from the sludge matrix by EDTA). While, at the end of the experiment, the SS reduction of EDTA-assisted bioaugmentation was $48.5 \%$, which was $34.3 \%$ higher than for the control (raw sludge) (Kavitha et al., 2013).

Contaminant removal in addition to bioaugmentation has been studied extensively with $T$. versicolor. García-Galán et al. (2011) completely (100\%) removed sulfonamide under environmental conditions. Rodríguez-Rodríguez et al. (2011, 2012) removed $3.8-99 \%$ of PCBs and $26-100 \%$ of PhACs under environmental conditions. They also showed that the removal of PhACs along with the production of laccases were higher in fungal bioaugmented sludge. Llorens-Blanch et al. (2018) used the bioaugmentation approach for the treatment of biopiles by T. versicolor. Out of $45 \mathrm{PhACs}$ investigated in the biopiles, only 19 were detected. They studied the effect of reinoculation of fungi at the middle of the period. The percentages for the total removal of PhACs after the end of the 42-day experiment of non reinoculated and reinoculated samples were 49.2 and $66.5 \%$, respectively During this study, they also analyzed microbial diversity in the biopiles system, and found that $T$. versicolor fungal colonization was predominant during the first half of the experiment (i.e., up to 23 days), but was no longer predominant by the end of the study. $\mathrm{PhAC}$ removal had improved in the re-inoculated biopiles. Moreover, a change in the fungal population hadn't affected the bacterial populations, which accelerated the contaminant removal (Llorens-Blanch et al., 2018). The VAPs obtained from the sludge valorization using aerobic bioaugmentation are listed in Table 3. The promising VAPs are biodiesel from Trichosporon oleaginosus (Zhang et al., 2014; Chen et al., 2021), enzymes from Aspergillus niger (Vaithyanathan et al., 2020), T. versicolor (Rodríguez-Rodríguez et al., 2011, 2014; LlorensBlanch et al., 2018) and Bacillus subtilis (Vaithyanathan et al., 2021b), biopesticide from B. thuringiensis, (Balasubramanian and Tyagi, 2017a; Cerda et al., 2019) and biosurfactant from Starmerella bombicola (Cerda et al., 2019). These products have future applications in extraction and production, and thus, provide a way for waste disposal and cost-effective production of VAPs.

\section{Anaerobic Digestion}

Bacillus cerus, a facultative anaerobe, which can be grown either with or without the presence of oxygen was investigated by Ushani et al. under anaerobic conditions. This strain was inoculated to sludge, which was pretreated with dioctyl sodium sulphosuccinate (DOSS) (Ushani et al., 2017b), sodium thiosulphate (Ushani et al., 2018), and magnesium sulfate 
TABLE 3 | Summary of key information on pre-treatment assisted bioaugmentation aided biological process.

\begin{tabular}{llll}
\hline \begin{tabular}{c} 
Type of pretreatment $\begin{array}{c}\text { Bioaugmented } \\
\text { microbes }\end{array}$ \\
\cline { 2 - 4 }
\end{tabular} & \multicolumn{3}{c}{ Sludge valorization } \\
\cline { 2 - 4 } & $\begin{array}{l}\text { Solids } \\
\text { reduction } \\
(\%)\end{array}$ & $\begin{array}{l}\text { COD } \\
\text { solubilization }\end{array}$ & $\begin{array}{l}\text { Contaminants Value added products } \\
\text { removal }(\%)\end{array}$ \\
& & & \\
& & &
\end{tabular}

\section{Anaerobic digestion}

Dioctyl sodium Bacillus sp $\quad 12.8 \% \quad 14 \%$

sulphosuccinate

Remarks

References

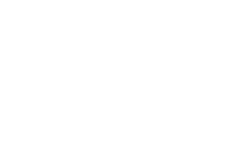

Bacillus sp

$17.4 \%$

$20 \%$

Sodium thiosulphate

Bacillus cerus

$12.8 \%$

$14 \%$

B. cerus

$21 \%$

$22 \%$

$\mathrm{MgSO} 4$

B. cerus

$12.8 \%$

$21 \%$

B. cerus

$19.2 \%$

$15.2 \%$

Exiguobacterium $15 \%$ spp.

$\mathrm{KOH}$ i) Methane

production- $0.18 \mathrm{~g} \mathrm{COD} / \mathrm{g}$ COD ii) maximum enzymatic activity of 0.32 $\mathrm{U} / \mathrm{mL}$ of protease and $0.02 \mathrm{U} / \mathrm{mL}$ of amylase

i) Methane production- $0.24 \mathrm{~g} \mathrm{COD} / \mathrm{g}$ COD ii) maximum enzymatic activity of 0.08 $\mathrm{U} / \mathrm{mL}$ of protease and $0.25 \mathrm{U} / \mathrm{mL}$ of amylase Methane production of $0.18 \mathrm{gCOD} / \mathrm{g}$ COD
Both experiments yield a net

Ushani et al. positive profit. However, bacterial disintegration yields (57.39 \$) higher compared to only bacterial integration of sludge (8.2\$) 2017b

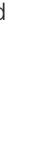

Net profit of 2.6 USD/ton of sludge was obtained with sodium thiosulphate aided bacterial disintegration where areas sludge disintegrated only with help of bacteria earned a negative net cost (-49.2 USD/ton of sludge).

Methane production of $0.32 \mathrm{gCOD} / \mathrm{g}$ COD

Maximum enzymatic activity of $0.33 \mathrm{U} / \mathrm{mL}$ of protease and $0.09 \mathrm{U} / \mathrm{mL}$ of amylase ii) Methane production of $235.8 \mathrm{~mL} / \mathrm{g}$ VS

i) Maximum enzymatic activity of $0.54 \mathrm{U} / \mathrm{mL}$ of protease and $0.28 \mathrm{U} / \mathrm{mL}$ of amylase ii) Methane production of $146.1 \mathrm{~mL} / \mathrm{g}$ VS

Methane production of $136 \mathrm{~mL} / \mathrm{g}$ VS
Net profit of 32.9 USD/ton of sludge was obtained with $\mathrm{MgSO}_{4}$ e aided bacterial disintegration where areas sludge disintegrated only with help of bacteria earned a negative net cost (-6.5 USD/ton of sludge).
Ushani et al. 2018

Ushani et al., $2017 a$ 
TABLE 3 | Continued

\begin{tabular}{|c|c|c|c|c|c|c|c|}
\hline \multirow{2}{*}{ Type of pretreatment } & \multirow{2}{*}{$\begin{array}{l}\text { Bioaugmented } \\
\text { microbes }\end{array}$} & \multicolumn{4}{|c|}{ Sludge valorization } & \multirow[t]{2}{*}{ Remarks } & \multirow[t]{2}{*}{ References } \\
\hline & & $\begin{array}{l}\text { Solids } \\
\text { reduction } \\
(\%)\end{array}$ & $\begin{array}{l}\text { COD } \\
\text { solubilization } \\
(\%)\end{array}$ & $\begin{array}{l}\text { Contaminants } \\
\text { removal }(\%)\end{array}$ & Value added products & & \\
\hline & $\begin{array}{l}\text { Bacillus jerish } 03 \\
\& \text { B. jerish } 04\end{array}$ & $314.9 \%$ & $10.5 \%$ & & $\begin{array}{l}\text { i) Maximum enzymatic } \\
\text { activity of } 0.04 \mathrm{U} / \mathrm{mL} \text { of } \\
\text { protease and } 0.06 \mathrm{U} / \mathrm{mL} \\
\text { of amylase ii) Methane } \\
\text { production of } 0.12 \\
\text { gCOD } / \mathrm{g} \text { COD }\end{array}$ & & \\
\hline \multirow[t]{2}{*}{$\mathrm{MgCl} 2$} & $\begin{array}{l}\text { B. jerish } 03 \& \text { \&. } \\
\text { jerish } 04\end{array}$ & $22.7 \%$ & $21.4 \%$ & & $\begin{array}{l}\text { i) Maximum enzymatic } \\
\text { activity of } 0.133 \mathrm{U} / \mathrm{mL} \text { of } \\
\text { protease and } 0.082 \mathrm{U} / \mathrm{mL} \\
\text { of amylase } \\
\text { ii) Methane production of } \\
0.22 \mathrm{gCOD} / \mathrm{g} \mathrm{COD}\end{array}$ & & \\
\hline & $\begin{array}{l}\text { Bacillus } \\
\text { licheniformis }\end{array}$ & & $\approx 12.1 \%$ & & $\begin{array}{l}\text { Biomethane } \approx 114 \mathrm{~mL} \\
\mathrm{CH} 4\end{array}$ & $\begin{array}{l}\text { Biomethane production is } 5.7 \\
\text { times higher compared to no } \\
\text { pretreatment }\end{array}$ & $\begin{array}{l}\text { Agabo-Garcia } \\
\text { et al., } 2019\end{array}$ \\
\hline \multicolumn{8}{|l|}{ Aerobic digestion } \\
\hline Ultrasonication & $\begin{array}{l}\text { B. jerish } 03 \text { \& B. } \\
\text { jerish } 04\end{array}$ & $20.7 \%$ & $23 \%$ & & $\begin{array}{l}\text { Maximum enzymatic } \\
\text { activity of } 0.15 \mathrm{U} / \mathrm{mL} \text { of } \\
\text { protease and } 0.12 \mathrm{U} / \mathrm{mL} \\
\text { of amylase }\end{array}$ & $\begin{array}{l}\text { Net profit of } 27 \text { USD/ton of } \\
\text { sludge was obtained with } \\
\text { ultrasonic aided bacterial } \\
\text { disintegration sludge } \\
\text { disintegrated only with help of } \\
\text { bacteria earned a negative net } \\
\text { cost (-6 USD/ton of sludge). }\end{array}$ & $\begin{array}{l}\text { Kavitha et al., } \\
\text { 2016c }\end{array}$ \\
\hline \multirow[t]{6}{*}{ Citric acid } & B. licheniformis & $18 \%$ & $10.9 \%$ & & & $\begin{array}{l}\text { Citric acid mediated bacterial } \\
\text { disintegration is cost effective } \\
\text { (₹0.24/day) when compared with } \\
\text { only bacterial disintegration. }\end{array}$ & $\begin{array}{l}\text { Merrylin et al., } \\
2014 b\end{array}$ \\
\hline & & $10 \%$ & $7.2 \%$ & & & & \\
\hline & B. thuringiensis & & & & $\begin{array}{l}\text { Biopesticides (max spore } \\
\text { count- } 8.15 \pm 0.04 \text { (107) } \\
\text { CFU g/DM. }\end{array}$ & $\begin{array}{l}\text { However, with different treatment } \\
\text { strategies, production yield of } \\
\text { value added products were low. }\end{array}$ & $\begin{array}{l}\text { t Cerda et al., } \\
2018\end{array}$ \\
\hline & $\begin{array}{l}\text { Starmerella } \\
\text { bombicola }\end{array}$ & & & & $\begin{array}{l}\text { Biosurfactant maximum } \\
\text { yield (Sophrolipids= } \\
0.02 \mathrm{~g} / \mathrm{g} \text {-DM }\end{array}$ & & \\
\hline & Ensifer sp & & & $\begin{array}{l}\text { Acetaminophen } \\
\text { removal }\end{array}$ & & $\begin{array}{l}\text { Compared to autochthonous } \\
\text { microbiota, Acetaminophen was } \\
\text { degraded in }<1 \mathrm{~h} \text { for Ensifer } \\
\text { bioaugmented samples which is } \\
22 \mathrm{~h} \text { for control }\end{array}$ & $\begin{array}{l}\text { Park and Oh, } \\
2020\end{array}$ \\
\hline & B. thuringiensis & & & & $\begin{array}{l}\text { Viable Cell count }-1.44 \times \\
10^{8} \mathrm{CFU} / \mathrm{mL} \\
\text { Sporulation rate-96\% }\end{array}$ & $\begin{array}{l}\text { Fenton oxidation based Bt using } \\
\text { sludge as a substrate is more } \\
\text { efficient when compared to } \\
\text { ultrasonication }\end{array}$ & $\begin{array}{l}\text { Pham et al., } \\
2010\end{array}$ \\
\hline
\end{tabular}


TABLE 3 | Continued

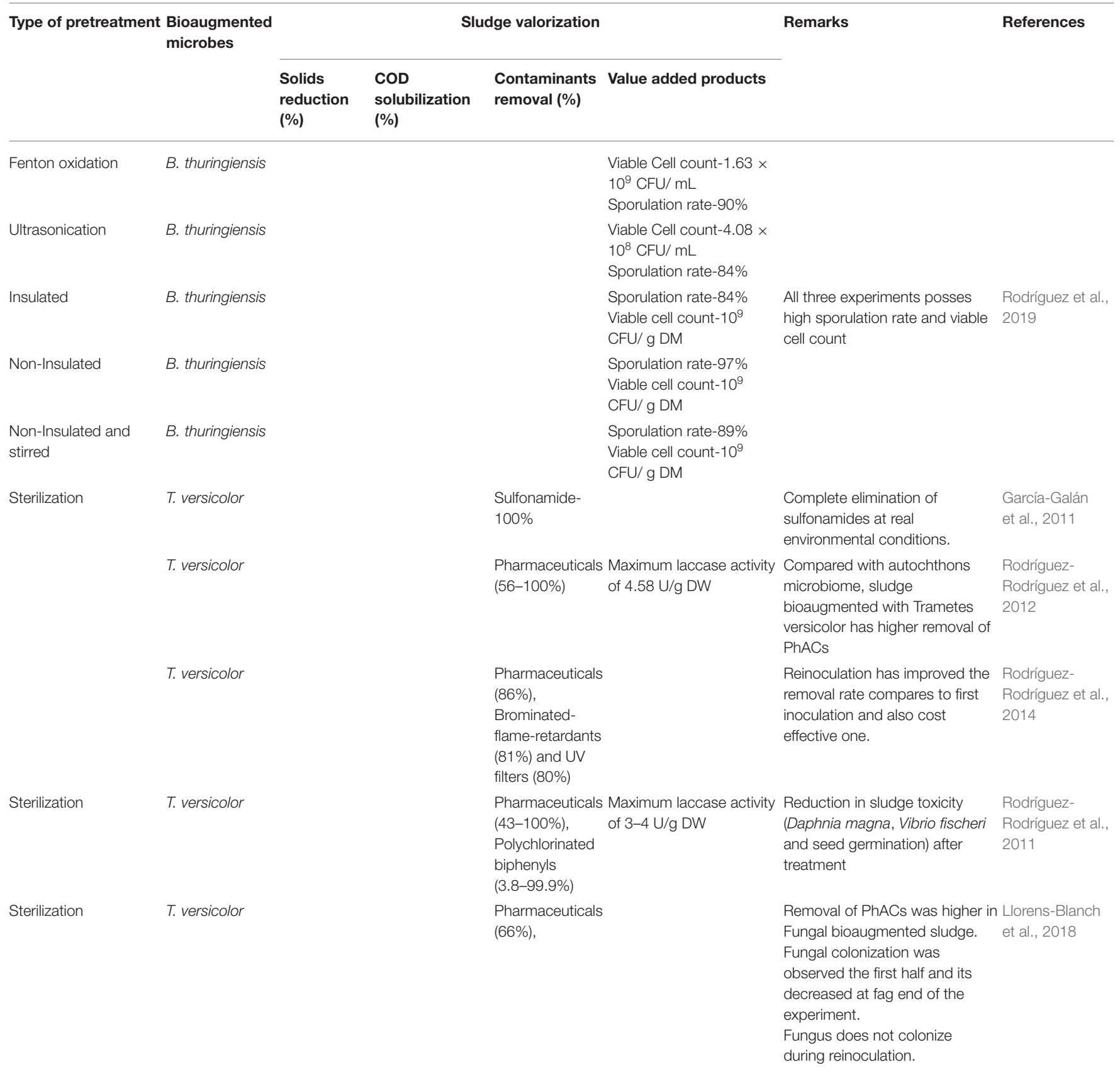

(Ushani et al., 2017a). During the study of DOSS pretreatment in anaerobic digestion, suspended solids, COD solubilization, methane production and enzyme activity were quantified. SS and COD reductions of 12.8 and $14 \%$ respectively, were obtained with initial bioaugmentation with only bacteria. Bioaugmentation also produced biomethane of $0.18 \mathrm{~g} \mathrm{COD} / \mathrm{g} \mathrm{COD}$ and with a meager net profit of US\$8.3/ton of wet sludge. However, addition of surfactant DOSS followed by bioaugmentation resulted in COD and SS reductions of almost 20 and $17.4 \%$ respectively. Although the results were not high, the methane production was $0.24 \mathrm{~g} \mathrm{COD} / \mathrm{g} \mathrm{COD}$ and the net profit was high at US\$57.39/ton of dried sludge compared to US $\$ 8.3 /$ ton of dried sludge for bioaugmentation, which was attributed to the immobilization of bacteria. Furthermore, the use of surfactant resulted in the release of protease and amylase (Ushani et al., 2017b). Sodium thiosulphate (Ushani et al., 2018) was used to induce the release of protease enzyme while simultaneously dispersing the flocs. The cost of the 
process was high due to the use of thiosulphate resulting in less profit. However, considering the VAPs, the release of protease and methane could compensate for the cost. This was comparatively profitable considering the cost of waste valorization without bioaugmentation which was net negative US\$49/ton of dried sludge (Ushani et al., 2018). Furthermore, $\mathrm{MgSO}_{4}$ had the highest deflocculating rate of $92 \%$ (Ushani et al., 2017a). However, this was not reflected on the suspended solids reduction and COD liquefaction but was evident by the high enzyme activities $(0.54 \mathrm{U} / \mathrm{mL}$ of protease and $0.28 \mathrm{U} / \mathrm{mL}$ of amylase).

While the anaerobic treatment has been extensively studied and optimized, it is still difficult to apply anaerobic conditions (Yu et al., 2020). This involves maintaining an oxygen-free environment, providing the required substrates, and proper release and storage of methane. It is evident from the above literary works that aerobic bioaugmentation reduces suspended solid content, increases COD solubilization, removes contaminants and provides VAP in demand. However, from the published results, the net profit is slightly greater under anaerobic fermentation due to biogas production which does not occur with aerobic digestion. The cost was calculated in accordance with the energy consumption of the pretreatment methods involved and the resultant VAP obtained. On the other hand, when infrastructure or equipment capital costs and operational costs are considered, the net cost of anaerobic treatment is slightly higher (Pfluger et al., 2019; Wainaina et al., 2020).

\section{MUNICIPAL SOLID WASTE REUSE AS RESOURCES-A BIOREFINERY PERSPECTIVE FOR THE PRODUCTION OF ADDED-VALUE PRODUCTS}

\section{Biodiesel}

The current trend of our ever-increasing global population and its use of petroleum-based products, predicts the depletion of these energy resources at a rapid rate. Moreover, environmental threats related to the use of these chemicals has led to the creation of an alternate pathway for the production of biobased products to alleviate GHGs and fulfill the global demand (Chen et al., 2018; Kumar et al., 2018; Dahiya, 2020).

Municipal sewage sludge, a potential feedstock, which consists of high lipid content and is available at zero cost, can be a viable alternative to producing biodiesel (Srivastava et al., 2018). Sewage sludge, which has been reported to contain 5-20\% lipid w/w dry sludge (Wang et al., 2016; Chen et al., 2018) and is rich in nutrients, can be used as the medium for microorganisms for lipid production, which constitutes an efficient way to reduce the cost of biodiesel production (Chen et al., 2018). Studies on biodiesel production in addition to bioaugmentation have been done extensively on oleaginous yeast species (Zhang et al., 2016; Selvakumar and Sivashanmugam, 2017; Chen et al., 2018, 2021; Selvakumar et al., 2019).
Microorganisms, which can accumulate more than 20\% (g/g) lipids, are known as oleaginous microorganisms. For lipid accumulation in microorganisms, a high $\mathrm{C} / \mathrm{N}$ ratio is required. In environmental conditions like sludge, lipid accumulation for microorganisms have been improved by introducing pretreatment methods (Bora et al., 2020). Municipal sludge with crude glycerol and $\mathrm{NH}_{4} \mathrm{Cl}$ was used for the production of lipid content by $T$. oleaginosus. After $60 \mathrm{~h}$, the lipid content and lipid concentration were $43.77 \%(\mathrm{w} / \mathrm{w})$, and $22.32 \mathrm{~g} / \mathrm{L}$, respectively. Moreover, the final estimated production cost of biodiesel was US\$630/ton of dried sludge, which was more competitive than the commercial biodiesel production cost (US\$900/ton of dried sludge) (Chen et al., 2021). Kumar et al. (2019) studied the thermo-sonic enzymatic PT of sludge with the subsequent addition of Naganishia liquefaciens for biodiesel production. The addition of yeast to thermal-sonic assisted enzymatic PT (TSEP) improved the lipid yield to 65.4\%, which was ten times higher than the undigested medium, and can be attributed to an adequate amount of nutrient release during TSEP (Selvakumar et al., 2019). Various PT assisted bioaugmentation, such as sonication (Zhang et al., 2016), thermo-chemo-sonic (Selvakumar and Sivashanmugam, 2017), chemical treatment (Zhang et al., 2014), to produce lipids for biodiesel production were studied (Table 4). Lipomyces starkeyi, an oleaginous yeast was reported to store a large amount of lipids in sludge media compared to other yeast considered for studies. Sonication prior to bioaugmentation was found to be a potential technology for lipid extraction since sonic irradiation, which causes bubbles to collapse, results in cell lysis as well as the release of lipids (Bora et al., 2020). For a higher yield of biodiesel production and lipid extraction from sewage sludge, primary sludge, and scum sludge, which contain more lipids, are potential feedstock compared to secondary sludge. However, for better biodiesel yield, a profiling database for sludge composition from the WWTPs is required (Liu et al., 2021).

\section{Bioplastics}

The demand for plastics is ever increasing due to its application in various fields including packaging, construction, medicine, agriculture, electrical, and automotive. But the detrimental effect of plastics on the environment is massive (Letcher, 2020; Qi et al., 2020). This global issue warrants an eco-friendly alternative for conventional plastic materials. Bioplastics produced from renewable biomass can sizably shrink the environmental ramifications of plastic usage. Polyhydroxyalkanoates (PHAs) and their derivatives are one of the major types of biodegradable and biocompatible bioplastics (Kumar et al., 2016). In the presence of sugar and lipids in the natural environment, some bacteria can produce PHAs, which are analogous to conventional plastics and can be used as an alternative to petroplastics. Moreover, products from microbial fermentation are biodegradable, which helps to protect the environment and human health. Municipal sludge, which is mainly comprised of carbohydrates and lipids, can be seen as a viable option for the production of bioplastics (Balasubramanian and Tyagi, 2017b). Among the various biorefinery-based products, the rapidly 
TABLE 4 | Summary of key information on VAP production by biological process.

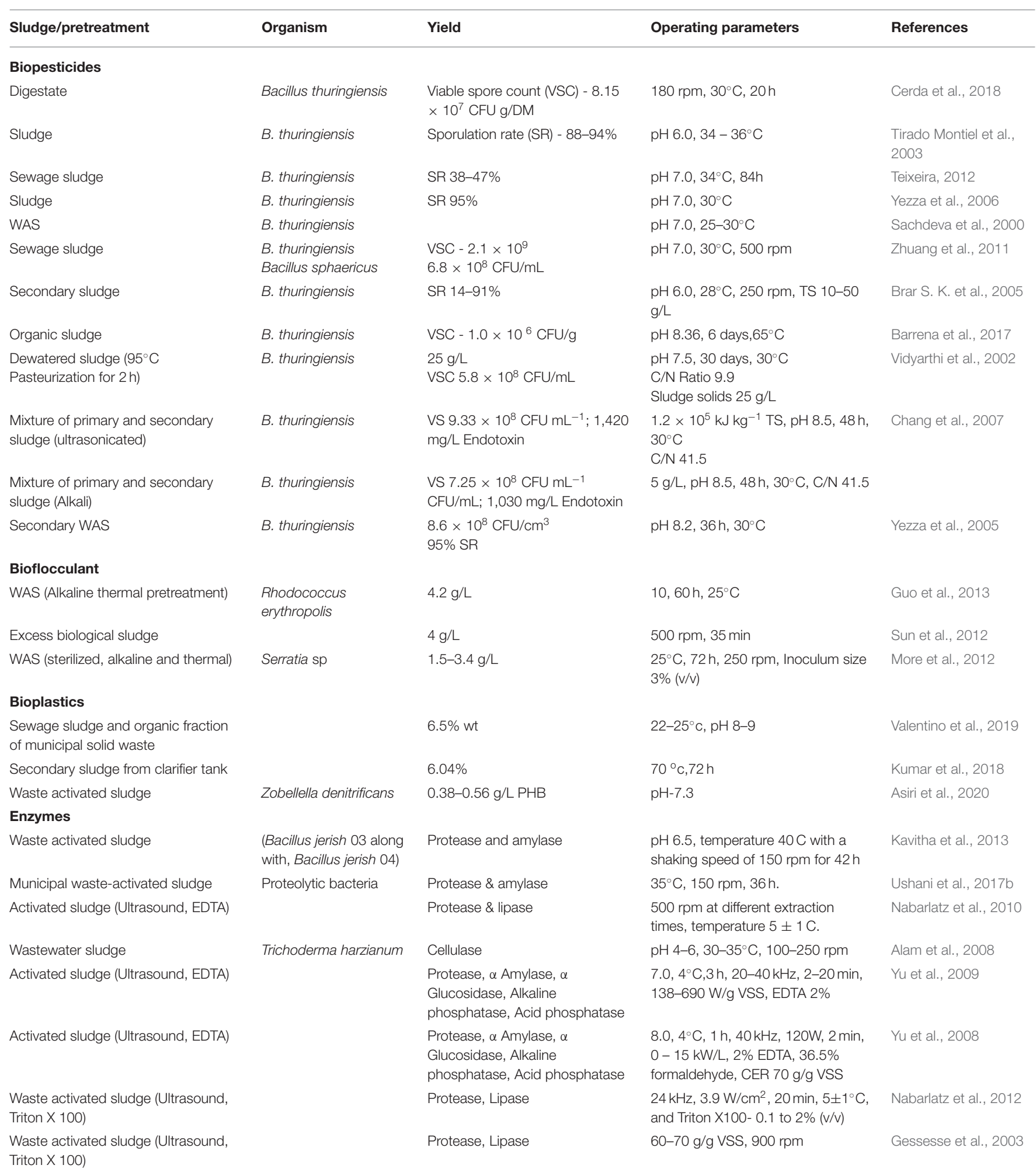


TABLE 4 | Continued

\begin{tabular}{|c|c|c|c|c|}
\hline Sludge/pretreatment & Organism & Yield & Operating parameters & References \\
\hline \multicolumn{5}{|l|}{ Biodiesel } \\
\hline Secondary sludge (Ultrasonication) & $\begin{array}{l}\text { Trichosporon } \\
\text { oleaginosus }\end{array}$ & $95 \%$ & $20-25^{\circ} \mathrm{C},(5-60 \mathrm{~min}$ & Zhang et al., 2016 \\
\hline Secondary sludge (Chemical-treated) & T. oleaginosus & Lipid content-39\% & $6.5,121^{\circ} \mathrm{C}$ for $15 \mathrm{~min}$ & Zhang et al., 2014 \\
\hline Sewage sludge & & $73.3 \%$ & $130{ }^{\circ} \mathrm{C}$ for $4 \mathrm{~h}$ & Zhang et al., 2020 \\
\hline
\end{tabular}

growing commodity is bioplastics and the CAGR of bioplastics will increase by about $16.6 \%$ by 2025 (Dahiya, 2020) (Table 4). In anaerobic digestion, during acidogenic fermentation when the methanogenic step is inhibited, waste activated sludge can be converted into volatile fatty acids (VFAs). VFAs with lower carbon mostly follow three different pathways, condensation, de nova and polymerization to convert the two acetyl CoA to PHAs in the presence of PHA synthase enzyme (Kumar et al., 2019). PHA content in waste activated sludge (WAS) has been reported to range from 0.3 to $22.7 \mathrm{mg}$ (Crutchik et al., 2020).

Asiri et al. (2020) investigated the bioaugmentation of Zobellella denitrificans in sludge under saline conditions for the production of $\mathrm{PHB}$, the most commonly used $\mathrm{PHA}$. C/N ratio, electron acceptors and saline factors affected the growth of $Z$. denitrificans and subsequent production of PHB. Increasing the saline conditions from no $\mathrm{NaCl}$ to $3 \% \mathrm{NaCl}$, the $\mathrm{PHB}$ production increased to $0.56 \mathrm{mg} / \mathrm{L}$ from $0.38 \mathrm{mg} / \mathrm{L}$ (Asiri et al., 2020). Mixing organic municipal solid waste and sewage sludge in a threestep mixed microbial culture (MMC) was investigated. In a fed batch test, MMC storing PHAs was able to accumulate $46 \% \mathrm{wt}$ of PHAs. However, while considering the mass flows in each process step and full-scale application, the overall yield of PHA was about 6.5\% wt (Valentino et al., 2019). Various parameters of secondary sludge were optimized using RSM, and a yield of about 6\% PHA was achieved, where the mcl PHA (58\%) was found to be dominant along with various PHA (Kumar et al., 2018) (Table 4).

\section{Bioflocculants}

Like bioplastics, bioflocculants are also naturally secreted by bacteria during their growth. Chemical flocculants or polymers, which are mostly used in wastewater treatment plants for coagulation-flocculation processes, are corrosive and toxic, and can cause adverse effects to the environment (Tyagi et al., 2009). Microbial flocculants, which are biodegradable can be used as a replacement for conventional polymers for a safe environment (Subramanian et al., 2010; More et al., 2012). However, the expensive substrate cost, which impacts the overall production cost, is the major limitation for their practical application. Sludge, a microbial rich source, which contains macromolecular compounds with flocculating activity, makes waste sludge a viable alternative option for high cost substrates for industrial applications (Guo et al., 2013) (Table 4).
Three different PT sludges (sterilization, alkali-thermal and acid-thermal) were used as raw material for Rhodococcus $R 3$ and Serratia sp inoculation by Guo et al. (2013) and More et al. (2012), respectively. Bioflocculant production in acid-thermal PT was low when compared with sterilization PT as well as alkali-thermal PT. The release of nutrients and their availability in medium, cell lysis and growth inhibition during the PT can be attributed to the production of bioflocculant. Bioflocculant production results in the release of nutrients and their bioavailability in the medium, and cell lysis and growth inhibition during the PT (Guo et al., 2013). Moreover, bioflocculant stability of alkaline thermal bioflocculant was investigated at varying temperatures and by adding enzymes. The flocculating rate decreased with an increase in temperature, and it only maintained up to $90 \%$ of its rate at relatively low temperatures $\left(60^{\circ} \mathrm{C}\right.$ for $\left.30 \mathrm{~min}\right)$. When the temperature was increased further to $80^{\circ} \mathrm{C}$, the rate decreased to $50 \%$. Addition of amylase, cellulase, glycoamylase, and glycosidase did not reduce the flocculation activity, which indicated that bioflocculant is neither a polysaccharide nor a glycoprotein. However, hydrolysis by pepsin and trypsin reduced the flocculation rate confirming that the bioingredient of the obtained flocculant is protein (Guo et al., 2013). Sun et al. (2012) studied the addition of $\mathrm{HCl}$ to sludge, and tested factors such as $\mathrm{pH}$, dosage, and temperature to optimize the production. The flocculating rate was high in the $\mathrm{pH}$ range of 5-11, at a dosage concentration above $1 \%$ and temperature $<40^{\circ} \mathrm{C}$. They also used $\mathrm{NaOH}$ and ethanol for purification and compared to ethanol, separation efficiency was effective with sodium hydroxide (Sun et al., 2012) (Table 4).

\section{Enzymes}

Enzymes, which increase the rate of a chemical reaction, have a commercial significance and are used for industrial applications. According to business communications company (BCC) research, the CAGR value of enzymes was expected to be $4.9 \%$ for the period of 2018 to 2023 (SaldarriagaHernández et al., 2020). Enzymes account for 30-40\% of the production cost for the preparation of culture medium in industries (Juwon and Emmanuel, 2012; Raheem et al., 2018). The organic matter of sludge is mainly comprised of carbohydrates, proteins, lipids, and enzymes such as amylase, protease, lipase, glycosidase and aminopeptidases, which play a part in biodegradation (Vaithyanathan et al., 2021a,b). So, its 
recovery is of high importance because of its use in various industrial applications such as pharmaceuticals, detergents, and food industries. Moreover, the recovered resource is from no/low cost waste, which reduces the industrial processing cost (Raheem et al., 2018). The vast microbial consortia present in sludge produce enzymes and release them into the medium to degrade the organic matter of sludge. Glucose oxidase (GOD) is one of the most important enzymes that can be produced by using this nutritious biomass from sludge. Vaithyanathan et al. (2020) proposed a cost-effective process to produce GOD using BS as a substrate by employing $A$. niger. A maximum GOD activity of $6012 \mathrm{U} / \mathrm{L}$ was achieved in $48 \mathrm{~h}$ when 72 -h old inoculum of $20 \%(\mathrm{w} / \mathrm{v})$ inoculum size was used in $25 \%(\mathrm{dw} / \mathrm{v}) \mathrm{BS}$ media. This approach can also simultaneously improve recalcitrant organic compound removal in treatment plants (Vaithyanathan et al., 2020).

The recovery of amylase and protease enzyme activities while adding EDTA prior to the addition of bacteria was studied. Enzyme activity in EPS-removed sludge improved to $0.18 \mathrm{U} / \mathrm{mL}$ from $0.08 \mathrm{U} / \mathrm{mL}$ for non-EPS removed sludge. The increase in enzyme activity may be due to the effective release of carbon and nitrogen sources as a result of the EDTA addition and subsequent utilization of nutrients by bacteria in the reactor (Kavitha et al., 2013). Similar studies were done by Ushani et al. where they used DOSS for EPS removal, and the enzyme activities in deflocculated sludge were higher compared to flocculated and control sludge. Along with the enzyme recovery, COD solubilization and biogas yield improved to $20 \%$ and $0.24 \mathrm{gCOD} / \mathrm{gCOD}$ respectively for deflocculated sludge from $14 \%$ and 0.18 $\mathrm{gCOD} / \mathrm{gCOD}$ respectively for flocculated sludge (Ushani et al., 2017b).

Nabarlatz et al. (2012), investigated the addition of Triton X100 along with ultrasonication of the sludge for the extraction of lipase and protease, and further used ammonium precipitation, dialysis and lyophilization as a purification procedure for the extracted lipase enzyme. Adding Triton X100 (0\% to 2\% v/v) to ultrasonic disintegration had a remarkable impact on the extraction of protease ( 0 to 52 protease units/g VSS) but, a negligible impact on lipase extraction (near constant and equal to 21 lipase units/g VSS). The extracted lipase underwent various purification studies, and of these studies, maximum recovery was obtained with ultrasonication $+0 \%$ Triton X $100+$ precipitation + lyophilization $(73.9 \%)$ followed by ultrasonication $+0 \%$ Triton X $100+$ dialysis + lyophilization, ultrasonication + $0 \%$ Triton X 100 + lyophilization (Nabarlatz et al., 2012) (Table 4).

\section{Biofertilizer}

The residual BS obtained after sludge treatment are a rich source of organic and inorganic plant nutrients and may be a realistic substitute for fertilizers (Singh and Agrawal, 2008). N-fertilizers originating from waste sludge and livestock manure could be a viable option for partially fulfilling manufactured fertilizer requirements, thus reducing its energy and resource footprint (Abeysiriwardana-Arachchige et al., 2020). Sewage sludge has microbial biomass that store beneficial amounts of nitrogen and phosphorous suitable for crop growth (Petersen et al., 2003). Sludge composts have nitrogen restoring capacities and can increase water retentivity in soil while circumventing non-point source pollution incurred by the use of commercial fertilizers (Monte et al., 2009). Various advancements in processes that convert different organic waste streams, including municipal solid waste, into biofertilizers were reviewed and field-tested by Du et al. (2020).

Aerobically digested sewage sludge yielded acceptable nitrogen fertilizer replacement value (NFRV) results compared with mineral reference treatments whereas the anaerobically digested sewage sludge required some additional N (Petersen et al., 2003). Ma et al. (2017) devised a biofertilizer production approach by co-digestion of activated sludge and fungal mash hydrolysed-food waste and described its economic feasibility (Ma et al., 2017). Sludge ash, a by-product obtained by incinerating dewatered sludge, was identified as a potential substrate to grow Rhizobium. Rhizobium can be used as inoculum to formulate biofertilizers with the capacity to induce high germination and nodulation in crops (Paliya et al., 2019). Benbrik et al. (2020) explored the application of phosphate sludge (i.e., sludge generated during the treatment of phosphate rock; many of the minerals removed constitute a sludge with phosphate in the insoluble form) supplied with phosphate solubilizing bacteria (PSB) to promote Zea Mays plant growth. The synergistic interaction of the microbial consortia of PSB could improve siderophores, $\mathrm{HCN}, \mathrm{H}_{2} \mathrm{~S}$, and most importantly Indol-3acetic acid production. It could also increase the solubility of P for easier plant uptake (Benbrik et al., 2020). The produced siderophores can also increase soil fertility and act as a biocontrol for fungal pathogens (Ali and Vidhale, 2013). On the other hand, the presence of TrOCs in biosolid-amended soil, could lead to the uptake of these contaminants into plants and subsequent possible risk of human exposure (Kinney and Heuvel, 2020). However, studies from Sabourin et al. (2012) and Gottschall et al. (2012), suggested that even though the vegetables harvested at the control site were high in TrOC concentration, the risk of human exposure to those TrOCs produced from biosolidamended soil was low (Gottschall et al., 2012; Sabourin et al., 2012). Plants uptake TrOCs from biosolid-amended soil by passive absorption of soil water through the epidermal layer root and into the root tissue cortex. These contaminants are then transported to other parts of the plants via simple diffusion and transpiration through xylem (Kinney and Heuvel, 2020). The bioaccumulation of TrOCs in vegetables (Sabourin et al., 2012) and earthworms (Sidhu et al., 2019) via biosolid-amended soil was observed.

\section{Biopesticides}

Biopesticides, a non-toxic residue to invertebrates, has a minimal impact on the environment compared to chemical pesticides. Biopesticides have the potential for effective pest control through bioactive microbial activity (Kiewnick, 2007) to increase the yield and quality of crops while circumventing the non-target toxicity and detrimental environmental impact incurred by the use of synthetic pesticides. Biopesticides have an added advantage of having a complex mode of action thereby delaying the resistance 
adaptation of the pests (Glare et al., 2012). According to the US market, the CAGR value of biopesticides will be $17 \%$ between the period of 2016 and 2022 (Arthurs and Dara, 2019). B. thuringiensis, bacteriophages and Trichoderma viride are some of the widely used species in biocontrol applications. Almost $90 \%$ of all biopesticide production experiments have been performed using the ubiquitous aerobic B. thuringiensis (Bt) (Sansinenea, 2012), which is known to be able to produce delta endotoxins ( $\delta$-endotoxin) during sporulation. The latter is widely used in agronomy, forestry and the public health sectors (Raheem et al., 2018; Zhang et al., 2018). However, the cost associated with the use of raw material for Bt inoculation is a major obstacle for its commercial application (Raheem et al., 2018).

Sludge can be used as a culture medium for Bt to produce value-added pesticides in a mineral rich culture medium. Bt inoculation in two bench-scale $(10 \mathrm{~L}$ and $22 \mathrm{~L})$ and one pilotscale reactors $(100 \mathrm{~L})$ were studied by Rodríguez et al. (2019) in insulated, non-insulated, stirred, and non-stirred conditions. In a non-temperature-controlled reactor $(10 \mathrm{~L})$, the viable cell count and spore counts increased from the beginning to reach a maximum at $72 \mathrm{~h}$ then decreased toward the end of the experiment $(96 \mathrm{~h})$. While in temperature-controlled and stirred conditions $(100 \mathrm{~L}$ and $22 \mathrm{~L})$, the viable cell counts decreased during the first $48 \mathrm{~h}$ and then gradually increased and became stable by the end of the experiment; the spore count, however, remained stable for the first $48 \mathrm{~h}$ and after that it started increasing until the end of experiment. The viable cells incremented to 1.9 -fold, 0.8 -fold, and 1.2 -fold respectively for $10 \mathrm{~L}, 22 \mathrm{~L}$, and $100 \mathrm{~L}$. The spore count incremented values were 171.6, 1.9 and 3.8 for $10 \mathrm{~L}, 22 \mathrm{~L}$, and $100 \mathrm{~L}$, respectively. The increase in viable cell counts and fast spore generation in nontemperature controlled conditions $(10 \mathrm{~L})$ compared to $22 \mathrm{~L}$ and $100 \mathrm{~L}$ can be attributed to the thermophilic conditions or lack of nutrients or stress in the solid matrix (Rodríguez et al., 2019) (Table 4). In another study, Bt kurstaki was used as inoculum for the fermentation of primary and secondary sludge. The lower entomotoxicity was observed at high sludge concentrations due to oxygen transfer limitations (Lachhab et al., 2001). Teixeira subjected sludge to alkaline PT, which increased the accessible nutrient content, which in turn increased the growth of Bt and entomoxicity. After fermentation followed by alkaline PT, the sporulation rate for sludge was in the range of $38-47 \%$; however, it was lower than the industrial TSB medium in which it was $65 \%$. The lower sporulation rate was obtained due to the presence of heavy metals and reduced oxygen concentration in the treated sludge. The lowest $\mathrm{LC}_{50}$ obtained during $\mathrm{Bt}$ sporulation was similar to TSB and showed its highest activity against Lepidoptera. Moreover, total solids concentration, and oxygen availability also play major roles in bacterial growth (Teixeira, 2012) (Table 4).

\section{FUTURE PROSPECTS AND CONCLUSION}

The industrial sludge treatment chemicals sector was valued at about US $\$ 4.5$ billion in 2016 and is expected to reach US $\$ 7.5$ billion by 2024 at a CAGR of about $6 \%$. The production rate of sludge is concerning environmentalists across the globe. But this nutrient and microbial rich matter can be viewed as a source of resources instead of as waste, which has made wastewater treatment experts consider the recovery of VAP from sludge. Increasing pressure from society, stringent disposal, an ever-increasing demand and rapid depletion of nonrenewable resources are the major factors behind this consensus. However, the presence of organic and inorganic contaminants, as well as pathogens, has impeded the use of sludge for resource recovery.

Sludge disposal techniques, such as land filling and incineration, require separate operational facilities and storage space and their associated costs are very high. In addition, the presence of toxic contaminants affects soil vegetation and further contaminates the groundwater, which, in turn, adversely affects the ecological system. Moreover, stringent disposal and societal concerns have made these disposal techniques relatively unacceptable for environmental application. Stabilization techniques, such as anaerobic/aerobic digestion, have been employed. These are eco-friendly and operationally feasible methods, which can significantly reduce the toxic content of sludge and are generally preferable before disposal. But the hydrolysis rate remains the major obstacle preventing sludge stabilization.

To overcome these limitations, physical, and chemical PT and their combinations could be applied prior to the biological process. Various physical PT techniques, such as ultrasonication, thermal, microwave, hydro cavitation, and others, were studied, and each PT was found to be successful under different applied circumstances. Out of the various PT techniques, ultrasonication and thermal treatment were preferred mostly because of low energy consumption and feasible operational conditions. While, in terms of chemical PT, the success rate was high for $\mathrm{NaOH}$ and ozonation related studies. These PT were effective in terms of sludge solubilization when applied separately, but in terms of VAP recovery, they were limited and less effective in contaminant removal.

On the other hand, PT assisted biological processes were found to be effective for sludge stabilization and VAP production. Furthermore, the addition of new bacterial formulations to PT assisted biologically processed sludge further enhanced sludge stabilization and helped in the production of numerous VAPs. The need to manage sludge would rapidly increase the demands for wastewater treatment procedures by global industries, generating large amounts of sludge. Thus, sludge as a recovery source is a good alternative for its management while complying with legislative requirements and circular economy principles. Three major parameters, sludge valorization, contaminant removal and VAP type, need to be considered before converting waste into an energy resource. However, only limited research has focused on all three parameters. Hence, more attention is required on all three of these parameters to obtain a highly economic, pollutant- 
free, odorless, and moreover socially acceptable resource in greater demand.

\section{AUTHOR CONTRIBUTIONS}

VV: writing-original draft, conceptualization, and manuscript designing. HC: investigation, funding acquisition, project administration, supervision, validation, and writing-review and

\section{REFERENCES}

Abeysiriwardana-Arachchige, I. S. A., Munasinghe-Arachchige, S. P., DelankaPedige, H. M. K., and Nirmalakhandan, N. (2020). Removal and recovery of nutrients from municipal sewage: Algal vs. conventional approaches. Water Res. 175:115709. doi: 10.1016/j.watres.2020.115709

Agabo-Garcia, C., Pérez, M., Rodríguez-Morgado, B., Parrado, J., and Solera, R. (2019). Biomethane production improvement by enzymatic pre-treatments and enhancers of sewage sludge anaerobic digestion. Fuel 255:115713. doi: 10.1016/j.fuel.2019.115713

Ahmad, T., Ahmad, K., and Alam, M. (2017). Sludge quantification at water treatment plant and its management scenario. Environ. Monit. Assess. 189, 1-10. doi: 10.1007/s10661-017-6166-1

Ahn, K. C., Zhao, B., Chen, J., Cherednichenko, G., Sanmarti, E., Denison, M. S., et al. (2008). In vitro biologic activities of the antimicrobials triclocarban, its analogs, and triclosan in bioassay screens: receptor-based bioassay screens. Environ. Health Perspect. 116, 1203-1210. doi: 10.1289/ehp.11200

Alam, M. Z., Muyibi, S. A., and Wahid, R. (2008). Statistical optimization of process conditions for cellulase production by liquid state bioconversion of domestic wastewater sludge. Bioresour. Technol. 99, 4709-4716. doi: 10.1016/j.biortech.2007.09.072

Ali, S. S., and Vidhale, N. N. (2013). Bacterial siderophore and their application: a review. Int. J. Curr. Microbiol. App. Sci. 2, 303-312.

Allied Market Research (2018). Waste Management Market by Type and Service: Global opportunity Analysis and Industry Forecast 2020-2027.

Anjum, M., Al-Makishah, N. H., and Barakat, M. A. (2016). Wastewater sludge stabilization using pre-treatment methods. Process Saf. Environ. Protect. 102, 615-632. doi: 10.1016/j.psep.2016.05.022

Appels, L., Baeyens, J., Degrève, J., and Dewil, R. (2008). Principles and potential of the anaerobic digestion of waste-activated sludge. Prog. Energy Combust. Sci. 34, 755-781. doi: 10.1016/j.pecs.2008.06.002

Appels, L., Houtmeyers, S., Degrève, J., Van Impe, J., and Dewil, R. (2013). Influence of microwave pre-treatment on sludge solubilization and pilot scale semi-continuous anaerobic digestion. Bioresour. Technol. 128, 598-603. doi: 10.1016/j.biortech.2012.11.007

Arthurs, S., and Dara, S. K. (2019). Microbial biopesticides for invertebrate pests and their markets in the United States. J. Invertebr. Pathol. 165, 13-21. doi: 10.1016/j.jip.2018.01.008

Asiri, F., Chen, C.-H., Hwangbo, M., Shao, Y., and Chu, K.-H. (2020). From organic wastes to bioplastics: feasibility of nonsterile poly (3-hydroxybutyrate) production by Zobellella denitrificans ZD1. ACS Omega 5, 24158-24168. doi: 10.1021/acsomega.9b04002

Aydin, S. (2016). Enhanced biodegradation of antibiotic combinations via the sequential treatment of the sludge resulting from pharmaceutical wastewater treatment using white-rot fungi Trametes versicolor and Bjerkandera adusta. Appl. Microbiol. Biotechnol. 100, 6491-6499. doi: 10.1007/s00253-016-7473-0

Bahreini, G., Nazari, L., Ho, D., Flannery, C. C., Elbeshbishy, E., Santoro, D., et al. (2020). Enzymatic pre-treatment for enhancement of primary sludge fermentation. Bioresour. Technol. 305:123071. doi: 10.1016/j.biortech.2020.123071

Balasubramanian, S., and Tyagi, R. D. (2017a). "Biopesticide production from solid wastes," in Current Developments in Biotechnology and Bioengineering (Elsevier), 43-58. doi: 10.1016/B978-0-444-63664-5.00003-4

Balasubramanian, S., and Tyagi, R. D. (2017b). "Value-added bio-products from sewage sludge," in Current Developments in Biotechnology and Bioengineering (Elsevier), 27-42. doi: 10.1016/B978-0-444-63664-5.00002-2 editing. Both authors contributed to the article and approved the submitted version.

\section{ACKNOWLEDGMENTS}

The authors express their deepest gratitude to the financial support extended by Natural Sciences and Engineering Research Council of Canada to facilitate our work.

Banu, J. R., Devi, T. P., Kannah, R. Y., Kavitha, S., Kim, S.-H., Muñoz, R., et al. (2021). A review on energy and cost effective phase separated pretreatment of biosolids. Water Res. 198:117169. doi: 10.1016/j.watres.2021.117169

Banu, J. R., Kannah, R. Y., Kavitha, S., Gunasekaran, M., and Kumar, G. (2018). Novel insights into scalability of biosurfactant combined microwave disintegration of sludge at alkali $\mathrm{pH}$ for achieving profitable bioenergy recovery and net profit. Bioresour. Technol. 267, 281-290. doi: 10.1016/j.biortech.2018.07.046

Banu, J. R., Ushani, U., Rajkumar, M., Kumar, R. N., and Karthikeyan, O. P. (2017). Impact of mild alkali dosage on immobilized Exiguobacterium spp. mediated cost and energy efficient sludge disintegration. Bioresour. Technol. 245, 434-441. doi: 10.1016/j.biortech.2017.08.216

Baran, S., Oleszczuk, P., and Baranowska, E. (2003). Degradation of Soil Environment in the Post-Flooding Area: Content of Polycyclic Aromatic Hydrocarbons (PAHs) and S-Triazine Herbicides. J. Environ. Sci. Health Part B 38, 799-812. doi: 10.1081/PFC-120025561

Barber, W. P. F. (2016). Thermal hydrolysis for sewage treatment: a critical review. Water Res. 104, 53-71. doi: 10.1016/j.watres.2016.07.069

Barnabé, S., Brar, S. K., Tyagi, R. D., Beauchesne, I., and Surampalli, R. Y. (2009). Pre-treatment and bioconversion of wastewater sludge to value-added products-Fate of endocrine disrupting compounds. Sci. Total Environ. 407, 1471-1488. doi: 10.1016/j.scitotenv.2008.11.015

Barrena, R., Artola, A., and Sánchez, A. (2017). A novel strategy for producing compost with enhanced biopesticide properties through solid-state fermentation of biowaste and inoculation with Bacillus thuringiensis. Waste Manage. 70, 53-58. doi: 10.1016/j.wasman.2017.09.041

Benbrik, B., Elabed, A., El Modafar, C., Douira, A., Amir, S., Filali-Maltouf, A., et al. (2020). Reusing phosphate sludge enriched by phosphate solubilizing bacteria as biofertilizer: growth promotion of Zea Mays. Biocatal. Agric. Biotechnol. 30:101825. doi: 10.1016/j.bcab.2020.101825

Bianchini, A., Bonfiglioli, L., Pellegrini, M., and Saccani, C. (2015). Sewage sludge drying process integration with a waste-to-energy power plant. Waste Manage. 42, 159-165. doi: 10.1016/j.wasman.2015.04.020

Bora, A. P., Gupta, D. P., and Durbha, K. S. (2020). Sewage sludge to bio-fuel: a review on the sustainable approach of transforming sewage waste to alternative fuel. Fuel 259:116262. doi: 10.1016/j.fuel.2019.116262

Brar, S. K., Verma, M., Tyagi, R. D., Valéro, J. R., and Surampalli, R. Y. (2005). Sludge based Bacillus thuringiensis biopesticides: viscosity impacts. Water Res. 39, 3001-3011. doi: 10.1016/j.watres.2005.04.072

Brown, S., Ippolito, J. A., Hundal, L. S., and Basta, N. T. (2020). Municipal biosolids-A resource for sustainable communities. Curr. Opin. Environ. Sci. Health 14, 56-62. doi: 10.1016/j.coesh.2020.02.007

Cao, K., Zhi, R., and Zhang, G. (2020). Photosynthetic bacteria wastewater treatment with the production of value-added products: a review. Bioresour. Technol. 299:122648. doi: 10.1016/j.biortech.2019.122648

CCME (2012). Canada-Wide Approach for the Management of Wastewater Biosolids. Canadian Council of Ministers of the Environment.

CCMEA (2010). Review of the Current Canadian Legislative Framework for Wastewater Biosolids. Canadian Council of Ministers of the Environment (CCMC).

Cerda, A., Artola, A., Barrena, R., Font, X., Gea, T., and Sánchez, A. (2019). Innovative production of bioproducts from organic waste through solid-state fermentation. Front. Sustain. Food Syst. 3:63. doi: 10.3389/fsufs.2019.00063

Cerda, A., Artola, A., Font, X., Barrena, R., Gea, T., and Sánchez, A. (2018). Composting of food wastes: status and challenges. Bioresour. Technol. 248, 57-67. doi: 10.1016/j.biortech.2017.06.133 
Chang, C.-J., Tyagi, V. K., and Lo, S.-L. (2011). Effects of microwave and alkali induced pretreatment on sludge solubilization and subsequent aerobic digestion. Bioresour. Technol. 102, 7633-7640. doi: 10.1016/j.biortech.2011.05.031

Chang, M., Zhou, S. G., Lu, N., and Ni, J. R. (2007). Enhanced Bacillus thuringiensis production from sewage sludge with alkaline and ultrasonic pretreatments. Water Air Soil Pollut. 186, 75-84. doi: 10.1007/s11270-007-9466-1

Chang, S.-H., Wu, C.-F., Yang, C.-F., and Lin, C.-W. (2021). Evaluation use of bioaugmentation and biostimulation to improve degradation of sulfolane in artificial groundwater. Chemosphere 263:127919. doi: 10.1016/j.chemosphere.2020.127919

Cheah, S., Jablonski, W. S., Olstad, J. L., Carpenter, D. L., Barthelemy, K. D., Robichaud, D. J., et al. (2016). Effects of thermal pretreatment and catalyst on biomass gasification efficiency and syngas composition. Green Chem. 18, 6291-6304. doi: 10.1039/C6GC01661H

Chen, J., Liu, S., Wang, Y., Huang, W., and Zhou, J. (2018). Effect of different hydrolytic enzymes pretreatment for improving the hydrolysis and biodegradability of waste activated sludge. Water Sci. Technol. 2017, 592-602. doi: 10.2166/wst.2018.185

Chen, J., Zhang, X., and Tyagi, R. D. (2021). Impact of nitrogen on the industrial feasibility of biodiesel production from lipid accumulated in oleaginous yeast with wastewater sludge and crude glycerol. Energy 217:119343. doi: 10.1016/j.energy.2020.119343

Chu, C. P., Lee, D. J., Chang, B.-V., You, C. S., and Tay, J. H. (2002). "Weak" ultrasonic pre-treatment on anaerobic digestion of flocculated activated biosolids. Water Res. 36, 2681-2688. doi: 10.1016/S0043-1354(01)00515-2

Climent, M., Ferrer, I., del Mar Baeza, M., Artola, A., Vázquez, F., and Font, X. (2007). Effects of thermal and mechanical pretreatments of secondary sludge on biogas production under thermophilic conditions. Chemical Eng. J. 133, 335-342. doi: 10.1016/j.cej.2007.02.020

Coma, M., Rovira, S., Canals, J., and Colprim, J. (2013). Minimization of sludge production by a side-stream reactor under anoxic conditions in a pilot plant. Bioresour. Technol. 129, 229-235. doi: 10.1016/j.biortech.2012.11.055

Coogan, M. A., Edziyie, R. E., La Point, T. W., and Venables, B. J. (2007). Algal bioaccumulation of triclocarban, triclosan, and methyl-triclosan in a North Texas wastewater treatment plant receiving stream. Chemosphere 67, 1911-1918. doi: 10.1016/j.chemosphere.2006.12.027

Coogan, M. A., and Point, T. W. L. (2008). Snail bioaccumulation of triclocarban, triclosan, and methyltriclosan in a North Texas, USA, stream affected by wastewater treatment plant runoff. Environ. Toxicol. Chem. 27, 1788-1793. doi: 10.1897/07-374.1

Crutchik, D., Franchi, O., Caminos, L., Jeison, D., Belmonte, M., Pedrouso, A., et al. (2020). Polyhydroxyalkanoates (PHAs) Production: A Feasible Economic Option for the Treatment of Sewage Sludge in Municipal Wastewater Treatment Plants? Water 12, 1118. doi: 10.3390/w12041118

Cycoń, M., Mrozik, A., and Piotrowska-Seget, Z. (2017). Bioaugmentation as a strategy for the remediation of pesticide-polluted soil: a review. Chemosphere 172, 52-71. doi: 10.1016/j.chemosphere.2016.12.129

Dahiya, A. (2020). "Chapter 32 - Biofuel conversion pathways service learning projects and case studies," in Bioenergy (Academic Press), 671-690. doi: 10.1016/B978-0-12-815497-7.00032-4

Dai, X., Luo, F., Dai, L., and Dong, B. (2013). Degradation of extracellular polymeric substances (EPS) in anaerobic digestion of dewatered sludge. Proc. Environ. Sci. 18, 515-521. doi: 10.1016/j.proenv.2013.04.069

Dantas, G., Sommer, M. O., Oluwasegun, R. D., and Church, G. M. (2008). Bacteria subsisting on antibiotics. Science 320, 100-103. doi: 10.1126/science. 1155157

Delibacak, S., Voronina, L., and Morachevskaya, E. (2020). Use of sewage sludge in agricultural soils: useful or harmful. Eur. J. Soil Sci. 9, 126-139. doi: $10.18393 /$ ejss.687052

d'Errico, G., Aloj, V., Ventorino, V., Bottiglieri, A., Comite, E., Ritieni, A., et al. (2020). Methyl t-butyl ether-degrading bacteria for bioremediation and biocontrol purposes. PLoS ONE 15:e0228936. doi: 10.1371/journal.pone.0228936

Dhar, B. R., Nakhla, G., and Ray, M. B. (2012). Techno-economic evaluation of ultrasound and thermal pretreatments for enhanced anaerobic digestion of municipal waste activated sludge. Waste Manage. 32, 542-549. doi: 10.1016/j.wasman.2011.10.007
Du, H., Parit, M., Wu, M., Che, X., Wang, Y., Zhang, M., et al. (2020). Sustainable valorization of paper mill sludge into cellulose nanofibrils and cellulose nanopaper. J. Hazard. Mater. 400:123106. doi: 10.1016/j.jhazmat.2020.123106

EMF (2015). Ellen MacArthur Foundation, SUN, McKinsey Centre for Business and Environment 2015. Growth Within: A Circular Economy Vision for a Competitive Europe. EMF.

Erden, G., Demir, O., and Filibeli, A. (2010). Disintegration of biological sludge: Effect of ozone oxidation and ultrasonic treatment on aerobic digestibility. Bioresour. Technol. 101, 8093-8098. doi: 10.1016/j.biortech.2010.06.019

Ernervik, A. (2011). A risk analysis of the potential harm on the soil environment caused by antibiotics in biosolids. Stud. Environ. Sci.

Eswari, A. P., Kavitha, S., Banu, J. R., Karthikeyan, O. P., and Yeom, I.-T. (2017) $\mathrm{H}_{2} \mathrm{O}_{2}$ induced cost effective microwave disintegration of dairy waste activated sludge in acidic environment for efficient biomethane generation. Bioresour. Technol. 244, 688-697. doi: 10.1016/j.biortech.2017.07.078

Eswari, P., Kavitha, S., Kaliappan, S., Yeom, I. T., and Banu, J. R. (2016). Enhancement of sludge anaerobic biodegradability by combined microwave$\mathrm{H}_{2} \mathrm{O}_{2}$ pretreatment in acidic conditions. Environ. Sci. Pollut. Res. 23, $13467-$ 13479. doi: 10.1007/s11356-016-6543-2

Fijalkowski, K., Rorat, A., Grobelak, A., and Kacprzak, M. J. (2017). The presence of contaminations in sewage sludge-The current situation. J. Environ. Manage. 203, 1126-1136. doi: 10.1016/j.jenvman.2017.05.068

Gao, N., Kamran, K., Quan, C., and Williams, P. T. (2020). Thermochemical conversion of sewage sludge: a critical review. Prog. Energy Combust. Sci. 79:100843. doi: 10.1016/j.pecs.2020.100843

Garcia-Blanco, S., Venosa, A. D., Suidan, M. T., Lee, K., Cobanli, S., and Haines, J. R. (2007). Biostimulation for the treatment of an oil-contaminated coastal salt marsh. Biodegradation 18, 1-15. doi: 10.1007/s10532-005-9029-3

García-Galán, M. J., Rodríguez-Rodríguez, C. E., Vicent, T., Caminal, G., Díaz Cruz, M. S., and Barceló, D. (2011). Biodegradation of sulfamethazine by Trametes versicolor: removal from sewage sludge and identification of intermediate products by UPLC-QqTOF-MS. Sci. Total Environ. 409, 5505-5512. doi: 10.1016/j.scitotenv.2011.08.022

Gatica, J., and Cytryn, E. (2013). Impact of treated wastewater irrigation on antibiotic resistance in the soil microbiome. Environ. Sci. Pollut. Res. 20, 3529-3538. doi: 10.1007/s11356-013-1505-4

Gayathri, T., Kavitha, S., Kumar, S. A., Kaliappan, S., Yeom, I. T., and Banu, J. R. (2015). Effect of citric acid induced deflocculation on the ultrasonic pretreatment efficiency of dairy waste activated sludge. Ultrason. Sonochem. 22, 333-340. doi: 10.1016/j.ultsonch.2014.07.017

Gentry, T., Rensing, C., and Pepper, I. A. N. (2004). New approaches for bioaugmentation as a remediation technology. Crit. Rev. Environ. Sci. Technol. 34, 447-494. doi: 10.1080/10643380490452362

Gessesse, A., Hatti-Kaul, R., Gashe, B. A., and Mattiasson, B. O. (2003). Novel alkaline proteases from alkaliphilic bacteria grown on chicken feather. Enzyme Microbial Technol. 32, 519-524. doi: 10.1016/S0141-0229(02)00324-1

Gherghel, A., Teodosiu, C., and De Gisi, S. (2019). A review on wastewater sludge valorisation and its challenges in the context of circular economy. J. Clean. Prod. 228, 244-263. doi: 10.1016/j.jclepro.2019.04.240

Glare, T., Caradus, J., Gelernter, W., Jackson, T., Keyhani, N., Köhl, J., et al. (2012). Have biopesticides come of age? Trends Biotechnol. 30, 250-258. doi: 10.1016/j.tibtech.2012.01.003

Goldstein, R. M., Mallory, L. M., and Alexander, M. (1985). Reasons for possible failure of inoculation to enhance biodegradation. Appl. Environ. Microbiol. 50, 977-983. doi: 10.1128/aem.50.4.977-983.1985

González-García, S., Rama, M., Cortés, A., García-Guaita, F., Núñez, A., Louro, L. G., et al. (2019). Embedding environmental, economic and social indicators in the evaluation of the sustainability of the municipalities of Galicia (northwest of Spain). J. Clean. Prod. 234, 27-42. doi: 10.1016/j.jclepro.2019.06.158

Gonzalez-Gil, L., Papa, M., Feretti, D., Ceretti, E., Mazzoleni, G., Steimberg, N., et al. (2016). Is anaerobic digestion effective for the removal of organic micropollutants and biological activities from sewage sludge? Water Res. 102, 211-220. doi: 10.1016/j.watres.2016.06.025

Gottschall, N., Topp, E., Metcalfe, C., Edwards, M., Payne, M., Kleywegt, S., et al. (2012). Pharmaceutical and personal care products in groundwater, subsurface drainage, soil, and wheat grain, following a high single application of municipal biosolids to a field. Chemosphere 87, 194-203. doi: 10.1016/j.chemosphere.2011.12.018 
Guan, R., Yuan, X., Wu, Z., Jiang, L., Li, Y., and Zeng, G. (2018). Principle and application of hydrogen peroxide based advanced oxidation processes in activated sludge treatment: a review. Chem. Eng. J. 339, 519-530. doi: 10.1016/j.cej.2018.01.153

Guo, J., Yang, C., and Zeng, G. (2013). Treatment of swine wastewater using chemically modified zeolite and bioflocculant from activated sludge. Bioresour. Technol. 143, 289-297. doi: 10.1016/j.biortech.2013.06.003

Haiba, E., Nei, L., Herodes, K., Ivask, M., and Lillenberg, M. (2018). On the degradation of metformin and carbamazepine residues in sewage sludge compost. EMU DSpace. doi: 10.15159/ar.18.123

Haiba, E., Nei, L., Kutti, S., Lillenberg, M., Herodes, K., Ivask, M., et al. (2017). Degradation of diclofenac and triclosan residues in sewage sludge compost. Agron. Res. 15, 395-405.

Haynes, R. J., Murtaza, G., and Naidu, R. (2009). Inorganic and organic constituents and contaminants of biosolids: implications for land application. Adv. Agron. 104, 165-267. doi: 10.1016/S0065-2113(09)04004-8

Higgins, C. P., Paesani, Z. J., Abbott Chalew, T. E., Halden, R. U., and Hundal, L. S. (2011). Persistence of triclocarban and triclosan in soils after land application of biosolids and bioaccumulation in Eisenia foetida. Environ. Toxicol. Chem. 30, 556-563. doi: 10.1002/etc.416

Iranzo, M., Gamón, M., Boluda, R., and Mormeneo, S. (2018). Analysis of pharmaceutical biodegradation of WWTP sludge using composting and identification of certain microorganisms involved in the process. Sci. Total Environ. 640, 840-848. doi: 10.1016/j.scitotenv.2018.05.366

Jain, S., Jain, S., Wolf, I. T., Lee, J., and Tong, Y. W. (2015). A comprehensive review on operating parameters and different pretreatment methodologies for anaerobic digestion of municipal solid waste. Renew. Sustain. Energy Rev. 52, 142-154. doi: 10.1016/j.rser.2015.07.091

Jaziri, K., Casellas, M., and Dagot, C. (2012). Comparing the effects of three pre-treatment disintegration techniques on aerobic sludge digestion: biodegradability enhancement and microbial community monitoring by PCRDGGE. Environ. Technol. 33, 1435-1444. doi: 10.1080/09593330.2011.632653

Jin, C., Archer, G., and Parker, W. (2018). Current status of sludge processing and biosolids disposition in Ontario. Resour. Conserv. Recycl. 137, 21-31. doi: 10.1016/j.resconrec.2018.05.024

Juwon, A. D., and Emmanuel, O. F. (2012). Experimental investigations on the effects of carbon and nitrogen sources on concomitant amylase and polygalacturonase production by Trichoderma viride BITRS-1001 in submerged fermentation. Biotechnol. Res. Int. 12, 1-8. doi: 10.1155/2012/904763

Kavitha, S., Banu, J. R., IvinShaju, C. D., Kaliappan, S., and Yeom, I. T. (2016a). Fenton mediated ultrasonic disintegration of sludge biomass: biodegradability studies, energetic assessment, and its economic viability. Bioresour. Technol. 221, 1-8. doi: 10.1016/j.biortech.2016.09.012

Kavitha, S., Banu, J. R., Kumar, J. V., and Rajkumar, M. (2016b). Improving the biogas production performance of municipal waste activated sludge via disperser induced microwave disintegration. Bioresour. Technol. 217, 21-27. doi: 10.1016/j.biortech.2016.02.034

Kavitha, S., Brindha, G. J., Gloriana, A. S., Rajashankar, K., Yeom, I. T., and Banu, J. R. (2016c). Enhancement of aerobic biodegradability potential of municipal waste activated sludge by ultrasonic aided bacterial disintegration. Bioresour. Technol. 200, 161-169. doi: 10.1016/j.biortech.2015.10.026

Kavitha, S., Jayashree, C., Kumar, S. A., Kaliappan, S., and Banu, J. R. (2014a). Enhancing the functional and economical efficiency of a novel combined thermo chemical disperser disintegration of waste activated sludge for biogas production. Bioresour. Technol. 173, 32-41. doi: 10.1016/j.biortech.2014.09.078

Kavitha, S., Kaliappan, S., Kumar, S. A., Yeom, I. T., and Banu, J. R. (2015). Effect of $\mathrm{NaCl}$ induced floc disruption on biological disintegration of sludge for enhanced biogas production. Bioresour. Technol. 192, 807-811. doi: 10.1016/j.biortech.2015.05.071

Kavitha, S., Kumar, S. A., Kaliappan, S., Yeom, I. T., and Banu, J. R. (2014b). Improving the amenability of municipal waste activated sludge for biological pretreatment by phase-separated sludge disintegration method. Bioresour. Technol. 169, 700-706. doi: 10.1016/j.biortech.2014.07.065

Kavitha, S., Kumar, S. A., Yogalakshmi, K., Kaliappan, S., and Banu, J. R. (2013). Effect of enzyme secreting bacterial pretreatment on enhancement of aerobic digestion potential of waste activated sludge interceded through EDTA. Bioresour. Technol. 150, 210-219. doi: 10.1016/j.biortech.2013.10.021
Kesari, K. K., Kumar, S., Verma, H. N., and Behari, J. (2011). Influence of ultrasonic treatment in sewage sludge. Hydrol. Curr. Res. 2:115.

Kiewnick, S. (2007). Practicalities of developing and registering microbial biological control agents. CAB Rev 2, 1-11. doi: 10.1079/PAVSNNR20072013

Kinney, C. A., Furlong, E. T., Zaugg, S. D., Burkhardt, M. R., Werner, S. L., Cahill, J. D., et al. (2006). Survey of organic wastewater contaminants in biosolids destined for land application. Environ. Sci. Technol. 40, 7207-7215. doi: 10.1021/es0603406

Kinney, C. A., and Heuvel, B. V. (2020). Translocation of pharmaceuticals and personal care products after land application of biosolids. Curr. Opin. Environ. Sci. Health 14, 23-30. doi: 10.1016/j.coesh.2019.11.004

Klečka, G. M., Staples, C. A., Clark, K. E., van der Hoeven, N., Thomas, D. E., and Hentges, S. G. (2009). Exposure analysis of bisphenol A in surface water systems in North America and Europe. Environ. Sci. Technol. 43, 6145-6150. doi: 10.1021/es900598e

Kor-Bicakci, G., and Eskicioglu, C. (2019). Recent developments on thermal municipal sludge pretreatment technologies for enhanced anaerobic digestion. Renew. Sustain. Energy Rev. 110, 423-443. doi: 10.1016/j.rser.2019.05.002

Kumar, A., Voropaeva, O., Maleva, M., Panikovskaya, K., Borisova, G., Rajkumar, M., et al. (2021). Bioaugmentation with copper tolerant endophyte Pseudomonas lurida strain EOO26 for improved plant growth and copper phytoremediation by Helianthus annuus. Chemosphere 266:128983. doi: 10.1016/j.chemosphere.2020.128983

Kumar, G., Ponnusamy, V. K., Bhosale, R. R., Shobana, S., Yoon, J.-J., Bhatia, S. K., et al. (2019). A review on the conversion of volatile fatty acids to polyhydroxyalkanoates using dark fermentative effluents from hydrogen production. Bioresour. Technol. 287:121427. doi: 10.1016/j.biortech.2019.121427

Kumar, M., Ghosh, P., Khosla, K., and Thakur, I. S. (2018). Recovery of polyhydroxyalkanoates from municipal secondary wastewater sludge. Bioresour. Technol. 255, 111-115. doi: 10.1016/j.biortech.2018. 01.031

Kumar, M., Gupta, A., and Thakur, I. S. (2016). Carbon dioxide sequestration by chemolithotrophic oleaginous bacteria for production and optimization of polyhydroxyalkanoate. Bioresour. Technol. 213, 249-256. doi: 10.1016/j.biortech.2016.02.038

Kumar, V., Chopra, A. K., and Kumar, A. (2017). A review on sewage sludge (Biosolids) a resource for sustainable agriculture. Arch. Agric. Environ. Sci. 2, 340-347. doi: 10.26832/24566632.2017.020417

Lachhab, K., Tyagi, R. D., and Valéro, J. R. (2001). Production of Bacillus thuringiensis biopesticides using wastewater sludge as a raw material: effect of inoculum and sludge solids concentration. Process Biochem. 37, 197-208. doi: 10.1016/S0032-9592(01)00198-4

Lee, H.-B., and Peart, T. E. (2000). Bisphenol A contamination in Canadian municipal and industrial wastewater and sludge samples. Water Qual. Res. J. 35, 283-298. doi: 10.2166/wqrj.2000.018

Lendvay, J. M., Löffler, F. E., Dollhopf, M., Aiello, M. R., Daniels, G., Fathepure, B. Z., et al. (2003). Bioreactive barriers: a comparison of bioaugmentation and biostimulation for chlorinated solvent remediation. Environ. Sci. Technol. 37, 1422-1431. doi: 10.1021/es025985u

Letcher, T. M. (2020). Plastic Waste and Recycling: Environmental Impact, Societal Issues, Prevention, and Solutions. Academic Press.

Li, F., Deng, D., Zeng, L., Abrams, S., and Li, M. (2021). Sequential anaerobic and aerobic bioaugmentation for commingled groundwater contamination of trichloroethene and 1, 4-dioxane. Sci. Total Environ. 774:145118. doi: 10.1016/j.scitotenv.2021.145118

Li, W., Yu, N., Fang, A., Liu, B., Ren, N., and Xing, D. (2019). Cotreatment of potassium ferrate and ultrasonication enhances degradability and dewaterability of waste activated sludge. Chem. Eng. J. 361, 148-155. doi: 10.1016/j.cej.2018.12.058

Lillenberg, M., Yurchenko, S., Kipper, K., Herodes, K., Pihl, V., Lõhmus, Ivask,M., et al. (2010). Presence of fluoroquinolones and sulfonamides in urban sewage sludge and their degradation as a result of composting. Int. J. Environ. Sci. Technol. 7, 307-312.

Lipińska, A., Wyszkowska, J., and Kucharski, J. (2021). Microbiological and biochemical activity in soil contaminated with pyrene subjected to bioaugmentation. Water Air Soil Pollut. 232, 1-18. doi: 10.1007/s11270-020-04950-y 
Liu, X., Zhu, F., Zhang, R., Zhao, L., and Qi, J. (2021). Recent progress on biodiesel production from municipal sewage sludge. Renew. Sustain. Energy Rev. 135:110260. doi: 10.1016/j.rser.2020.110260

Llorens-Blanch, G., Parladé, E., Martinez-Alonso, M., Gaju, N., Caminal, G., and Blánquez, P. (2018). A comparison between biostimulation and bioaugmentation in a solid treatment of anaerobic sludge: drug content and microbial evaluation. Waste Manage. 72, 206-217. doi: 10.1016/j.wasman.2017.10.048

Luo, Y., Guo, W., Ngo, H. H., Nghiem, L. D., Hai, F. I., Zhang, J., et al. (2014). A review on the occurrence of micropollutants in the aquatic environment and their fate and removal during wastewater treatment. Sci. Total Environ. 473, 619-641. doi: 10.1016/j.scitotenv.2013.12.065

Ma, Y., Yin, Y., and Liu, Y. (2017). New insights into co-digestion of activated sludge and food waste: Biogas versus biofertilizer. Bioresour. Technol. 241, 448-453. doi: 10.1016/j.biortech.2017.05.154

Mancuso, G., Langone, M., and Andreottola, G. (2020). A critical review of the current technologies in wastewater treatment plants by using hydrodynamic cavitation process: principles and applications. J. Environ. Health Sci. Eng. 18, 311-333. doi: 10.1007/s40201-020-00444-5

Mancuso, G., Langone, M., Andreottola, G., and Bruni, L. (2019). Effects of hydrodynamic cavitation, low-level thermal and low-level alkaline pre-treatments on sludge solubilisation. Ultrason. Sonochem. 59:104750. doi: 10.1016/j.ultsonch.2019.104750

Marguí, E., Iglesias, M., Camps, F., Sala, L., and Hidalgo, M. (2016). Long-term use of biosolids as organic fertilizers in agricultural soils: potentially toxic elements occurrence and mobility. Environ. Sci. Pollut. Res. 23, 4454-4464. doi: 10.1007/s11356-015-5618-9

Martín, J., Santos, J. L., Aparicio, I., and Alonso, E. (2015). Pharmaceutically active compounds in sludge stabilization treatments: anaerobic and aerobic digestion, wastewater stabilization ponds and composting. Sci. Total Environ. 503, 97-104. doi: 10.1016/j.scitotenv.2014.05.089

Merrylin, J., Kaliappan, S., Kumar, S. A., Yeom, I. T., and Banu, J. R. (2014a). Effect of extra polymeric substance removal on sludge reduction potential of B acillus licheniformis at its optimised $\mathrm{pH}$ condition. Water Environ. J. 28, 95-103. doi: 10.1111/wej.12014

Merrylin, J., Kaliappan, S., Kumar, S. A., Yeom, I. T., and Banu, J. R. (2014b). Enhancing aerobic digestion potential of municipal waste-activated sludge through removal of extracellular polymeric substance. Environ. Sci. Poll. Res. 21, 1112-1123. doi: 10.1007/s11356-013-1976-3

Mininni, G., Blanch, A. R., Lucena, F., and Berselli, S. (2015). EU policy on sewage sludge utilization and perspectives on new approaches of sludge management. Environ. Sci. Pollut. Res. 22, 7361-7374. doi: 10.1007/s11356-014-3132-0

Mohajerani, A., and Karabatak, B. (2020). Microplastics and pollutants in biosolids have contaminated agricultural soils: an analytical study and a proposal to cease the use of biosolids in farmlands and utilise them in sustainable bricks. Waste Manage. 107, 252-265. doi: 10.1016/j.wasman.2020.04.021

Mohajerani, A., Lound, S., Liassos, G., Kurmus, H., Ukwatta, A., and Nazari, M. (2017). Physical, mechanical and chemical properties of biosolids and raw brown coal fly ash, and their combination for road structural fill applications. J. Clean. Prod. 166, 1-11. doi: 10.1016/j.jclepro.2017.07.250

Monte, M. C., Fuente, E., Blanco, A., and Negro, C. (2009). Waste management from pulp and paper production in the European Union. Waste Manage. 29, 293-308. doi: 10.1016/j.wasman.2008.02.002

More, T. T., Yan, S., Hoang, N. V., Tyagi, R. D., and Surampalli, R. Y. (2012). Bacterial polymer production using pre-treated sludge as raw material and its flocculation and dewatering potential. Bioresource Technol. 121, 425-431. doi: 10.1016/j.biortech.2012.06.075

Müller, J. A. (2001). Prospects and problems of sludge pre-treatment processes. Water Sci. Technol. 44, 121-128. doi: 10.2166/wst.2001.0598

Nabarlatz, D., Stüber, F., Font, J., Fortuny, A., Fabregat, A., and Bengoa, C. (2012). Extraction and purification of hydrolytic enzymes from activated sludge. Resour. Conserv. Recycl. 59, 9-13. doi: 10.1016/j.resconrec.2011.06.017

Nabarlatz, D., Vondrysova, J., Jenicek, P., Stüber, F., Font, J., Fortuny, A., et al. (2010). Hydrolytic enzymes in activated sludge: extraction of protease and lipase by stirring and ultrasonication. Ultrasonics Sonochem. 17, 923-931. doi: 10.1016/j.ultsonch.2010.02.006

Nazari, L., Sarathy, S., Santoro, D., Ho, D., Ray, M. B., and Xu, C. C. (2018). "Recent advances in energy recovery from wastewater sludge," in Direct Thermochemical Liquefaction for Energy Applications (Elsevier), 67-100. doi: 10.1016/B978-0-08-101029-7.00011-4
Nguyen, V. K., Chaudhary, D. K., Dahal, R. H., Trinh, N. H., Kim, J., Chang, S. W., et al. (2021). Review on pretreatment techniques to improve anaerobic digestion of sewage sludge. Fuel 285:119105. doi: 10.1016/j.fuel.2020.119105

Packyam, G. S., Kavitha, S., Kumar, S. A., Kaliappan, S., Yeom, I. T., and Banu, J. R. (2015). Effect of sonically induced deflocculation on the efficiency of ozone mediated partial sludge disintegration for improved production of biogas. Ultrason. Sonochem. 26, 241-248. doi: 10.1016/j.ultsonch.2015.01.015

Paliya, S., Mandpe, A., Kumar, S., and Kumar, M. S. (2019). Enhanced nodulation and higher germination using sludge ash as a carrier for biofertilizer production. J. Environ. Manage. 250:109523. doi: 10.1016/j.jenvman.2019.109523

Pappu, A., Saxena, M., and Asolekar, S. R. (2007). Solid wastes generation in India and their recycling potential in building materials. Build. Environ. 42, 2311-2320. doi: 10.1016/j.buildenv.2006.04.015

Park, S., and Oh, S. (2020). Detoxification and bioaugmentation potential for acetaminophen and its derivatives using Ensifer sp. isolated from activated sludge. Chemosphere 260:127532. doi: 10.1016/j.chemosphere.2020.127532

Petersen, S. O., Henriksen, K., Mortensen, G. K., Krogh, P. H., Brandt, K. K., Sørensen, J., et al. (2003). Recycling of sewage sludge and household compost to arable land: fate and effects of organic contaminants, and impact on soil fertility. Soil and Tillage Res. 72, 139-152. doi: 10.1016/S0167-1987(03)00084-9

Pfluger, A., Coontz, J., Zhiteneva, V., Gulliver, T., Cherry, L., Cavanaugh, L., et al. (2019). Anaerobic digestion and biogas beneficial use at municipal wastewater treatment facilities in Colorado: a case study examining barriers to widespread implementation. J. Clean. Prod. 206, 97-107. doi: 10.1016/j.jclepro.2018.09.161

Pham, T. T. H., Brar, S. K., Tyagi, R. D., and Surampalli, R. Y. (2010). Optimization of Fenton oxidation pre-treatment for B. thuringiensis-based production of value added products from wastewater sludge. J. Environ. Manage. 91, 1657-1664. doi: 10.1016/j.jenvman.2010.03.007

Pilli, S., Yan, S., Tyagi, R. D., and Surampalli, R. Y. (2015). Thermal pretreatment of sewage sludge to enhance anaerobic digestion: a review. Crit. Rev. Environ. Sci. Technol. 45, 669-702. doi: 10.1080/10643389.2013.876527

Qi, C., Yang, W., He, F., and Yao, J. (2020). The thermal properties and degradability of chiral polyester-imides based on several 1/d-amino acids. Polymers 12:2053. doi: 10.3390/polym12092053

Qian, L., Wang, S., Xu, D., Guo, Y., Tang, X., and Wang, L. (2016). Treatment of municipal sewage sludge in supercritical water: a review. Water Res. 89, 118-131. doi: 10.1016/j.watres.2015.11.047

Raheem, A., Sikarwar, V. S., He, J., Dastyar, W., Dionysiou, D. D., Wang, W., et al. (2018). Opportunities and challenges in sustainable treatment and resource reuse of sewage sludge: a review. Chem. Eng. J. 337, 616-641. doi: 10.1016/j.cej.2017.12.149

Raper, E., Stephenson, T., Anderson, D. R., Fisher, R., and Soares, A. (2018). Industrial wastewater treatment through bioaugmentation. Proc. Saf. Environ. Protect. 118, 178-187. doi: 10.1016/j.psep.2018.06.035

Rathankumar, A. K., Saikia, K., Nagarajan, K. T., Vaithyanathan, V. K., Vaidyanathan, V. K., and Cabana, H. (2020). Development of efficient and sustainable added-value products from municipal biosolids through an industrially feasible process. J. Clean. Prod. 2020:121749. doi: $10.1016 /$ j.jclepro.2020.121749

Rodríguez, P., Cerda, A., Font, X., Sánchez, A., and Artola, A. (2019). Valorisation of biowaste digestate through solid state fermentation to produce biopesticides from Bacillus thuringiensis. Waste Manage. 93, 63-71. doi: 10.1016/j.wasman.2019.05.026

Rodríguez-Rodríguez, C. E., Barón, E., Gago-Ferrero, P., Jelić, A., Llorca, M., Farré, M., et al. (2012). Removal of pharmaceuticals, polybrominated flame retardants and UV-filters from sludge by the fungus Trametes versicolor in bioslurry reactor. J. Hazard. Mater. 233, 235-243. doi: 10.1016/j.jhazmat.2012. 07.024

Rodríguez-Rodríguez, C. E., Jelić, A., Llorca, M., Farré, M., Caminal, G., Petrović, M., et al. (2011). Solid-phase treatment with the fungus Trametes versicolor substantially reduces pharmaceutical concentrations and toxicity from sewage sludge. Bioresour. Technol. 102, 5602-5608. doi: 10.1016/j.biortech.2011.02.029

Rodríguez-Rodríguez, C. E., Lucas, D., Barón, E., Gago-Ferrero, P., Molins-Delgado, D., Rodríguez-Mozaz, S., et al. (2014). Re-inoculation strategies enhance the degradation of emerging pollutants in fungal bioaugmentation of sewage sludge. Bioresour. Technol. 168, 180-189. doi: 10.1016/j.biortech.2014.01.124

Roy, A., Dutta, A., Pal, S., Gupta, A., Sarkar, J., Chatterjee, A., et al. (2018). Biostimulation and bioaugmentation of native microbial community 
accelerated bioremediation of oil refinery sludge. Bioresour. Technol. 253, 22-32. doi: 10.1016/j.biortech.2018.01.004

Sabourin, L., Duenk, P., Bonte-Gelok, S., Payne, M., Lapen, D. R., and Topp, E. (2012). Uptake of pharmaceuticals, hormones and parabens into vegetables grown in soil fertilized with municipal biosolids. Sci. Total Environ. 431, 233-236. doi: 10.1016/j.scitotenv.2012.05.017

Sachdeva, V., Tyagi, R. D., and Valero, J. R. (2000). Production of biopesticides as a novel method of wastewater sludge utilization/disposal. Water Sci. Technol. 42, 211-216. doi: 10.2166/wst.2000.0209

Saetea, P., and Tippayawong, N. (2013). Recovery of value-added products from hydrothermal carbonization of sewage sludge. Int. Scholarly Res. Notices 2013:268947. doi: 10.1155/2013/268947

Şahinkaya, S., and Sevimli, M. F. (2013). Sono-thermal pre-treatment of waste activated sludge before anaerobic digestion. Ultrason. Sonochem. 20, 587-594. doi: 10.1016/j.ultsonch.2012.07.006

Saldarriaga-Hernández, S., Velasco-Ayala, C., Flores, P. L.-I., de Jesús RostroAlanis, M., Parra-Saldivar, R., Iqbal, H. M., et al. (2020). Biotransformation of lignocellulosic biomass into industrially relevant products with the aid of fungi-derived lignocellulolytic enzymes. Int. J. Biol. Macromol. 161, 1099-1116. doi: 10.1016/j.ijbiomac.2020.06.047

Salsabil, M. R., Laurent, J., Casellas, M., and Dagot, C. (2010). Techno-economic evaluation of thermal treatment, ozonation and sonication for the reduction of wastewater biomass volume before aerobic or anaerobic digestion. J. Hazard. Mater. 174, 323-333. doi: 10.1016/j.jhazmat.2009.09.054

Sansinenea, E. (2012). Bacillus Thuringiensis Biotechnology. Springer. doi: 10.1007/978-94-007-3021-2

Selvakumar, P., Arunagiri, A., and Sivashanmugam, P. (2019). Thermo-sonic assisted enzymatic pre-treatment of sludge biomass as potential feedstock for oleaginous yeast cultivation to produce biodiesel. Renew. Energy 139, 1400-1411. doi: 10.1016/j.renene.2019.03.040

Selvakumar, P., and Sivashanmugam, P. (2017). Thermo-chemo-sonic predigestion of waste activated sludge for yeast cultivation to extract lipids for biodiesel production. J. Environ. Manage. 198, 90-98. doi: 10.1016/j.jenvman.2017.04.064

Semblante, G. U., Hai, F. I., Huang, X., Ball, A. S., Price, W. E., and Nghiem, L. D. (2015). Trace organic contaminants in biosolids: impact of conventional wastewater and sludge processing technologies and emerging alternatives. J. Hazard. Mater. 300, 1-17. doi: 10.1016/j.jhazmat.2015.06.037

Seo, K. W., Choi, Y.-S., Gu, M. B., Kwon, E. E., Tsang, Y. F., Rinklebe, J., et al. (2017). Pilot-scale investigation of sludge reduction in aerobic digestion system with endospore-forming bacteria. Chemosphere 186, 202-208. doi: 10.1016/j.chemosphere.2017.07.150

SeŽun, M., Kosel, J., Zupanc, M., Hočevar, M., Vrtovšek, J., Petkovšek, M., et al. (2019). Cavitation as a potential technology for wastewater management: an example of enhanced nutrient release from secondary pulp and paper mill sludge. Strojniški vestnik 65, 641-649. doi: 10.5545/sv-jme.2019.6328

Sharma, B., and Jain, P. (2020). Deciphering the advances in bioaugmentation of plastic wastes. J. Clean. Prod. 2020:123241. doi: 10.1016/j.jclepro.2020.123241

Sharma, B., Sarkar, A., Singh, P., and Singh, R. P. (2017). Agricultural utilization of biosolids: a review on potential effects on soil and plant grown. Waste Manage. 64, 117-132. doi: 10.1016/j.wasman.2017.03.002

Siddique, M. N. I., and Wahid, Z. A. (2018). Achievements and perspectives of anaerobic co-digestion: a review. J. Clean. Prod. 194, 359-371. doi: 10.1016/j.jclepro.2018.05.155

Sidhu, H., O’Connor, G., Ogram, A., and Kumar, K. (2019). Bioavailability of biosolids-borne ciprofloxacin and azithromycin to terrestrial organisms: microbial toxicity and earthworm responses. Sci. Total Environ. 650, 18-26. doi: 10.1016/j.scitotenv.2018.09.004

Singh, R. P., and Agrawal, M. (2008). Potential benefits and risks of land application of sewage sludge. Waste Manage. 28, 347-358. doi: 10.1016/j.wasman.2006.12.010

Srivastava, N., Srivastava, M., Gupta, V. K., Manikanta, A., Mishra, K., Singh, S., et al. (2018). Recent development on sustainable biodiesel production using sewage sludge. 3 Biotech 8, 1-11. doi: 10.1007/s13205-018-1264-5

Subramanian, S. B., Yan, S., Tyagi, R. D., and Surampalli, R. Y. (2010). Extracellular polymeric substances (EPS) producing bacterial strains of municipal wastewater sludge: isolation, molecular identification, EPS characterization and performance for sludge settling and dewatering. Water Res. 44, 2253-2266. doi: 10.1016/j.watres.2009.12.046

Suksiripattanapong, C., Horpibulsuk, S., Chanprasert, P., Sukmak, P., and Arulrajah, A. (2015). Compressive strength development in fly ash geopolymer masonry units manufactured from water treatment sludge. Construct. Build. Mater. 82, 20-30. doi: 10.1016/j.conbuildmat.2015.02.040

Sullivan, D. M., Cogger, C. G. and Bary, A. I. (2015). Sullivan, D. M., Cogger, C. G., and Bary, A. I. (2015). Fertilizing With Biosolids. A Pacific Northwest Extension Publication PNW 508. Oregon State University, University of Idaho, Washington State University.

Sun, J., Zhang, X., Miao, X., and Zhou, J. (2012). Preparation and characteristics of bioflocculants from excess biological sludge. Bioresour. Technol. 126, 362-366. doi: 10.1016/j.biortech.2012.08.042

Sun, Y., Liu, Y., Zhang, Y., Huang, Y., Wang, L., Dai, L., et al. (2019). Hydrocyclone-induced pretreatment for sludge solubilization to enhance anaerobic digestion. Chem. Eng. J. 374, 1364-1372. doi: 10.1016/j.cej.2019.05.159

Tas, D. O., Yangin-Gomec, C., Olmez-Hanci, T., Arikan, O. A., Cifci, D. I., Gencsoy, E. B., et al. (2018). Comparative assessment of sludge pre-treatment techniques to enhance sludge dewaterability and biogas production. Clean Soil Air Water 46:1700569. doi: 10.1002/clen.201700569

Teixeira, M. B. (2012). Using sewage sludge from Municipal and Industrial Solid Wastes to produce a Bacillus thuringiensis Biopesticide (Doctoral dissertation).

Tirado Montiel, M. L., Tyagi, R. D., Valero, J. R., and Surampalli, R. Y. (2003). Production of biopesticides using wastewater sludge as a raw material-effect of process parameters. Water Sci. Technol. 48, 239-246. doi: 10.2166/wst.2003.0474

Toreci, I., Kennedy, K. J., and Droste, R. L. (2009). Evaluation of continuous mesophilic anaerobic sludge digestion after high temperature microwave pretreatment. Water Res. 43, 1273-1284. doi: 10.1016/j.watres.2008.12.022

Tyagi, R. D., Surampalli, R. Y., Yan, S., Zhang, T. C., Kao, C. M., and Lohani, B. N. (2009). Sustainable Sludge Management: Production of Value Added Products. American Society of Civil Engineers. doi: 10.1061/9780784410516

Tyagi, V. K., and Lo, S.-L. (2011). Application of physico-chemical pretreatment methods to enhance the sludge disintegration and subsequent anaerobic digestion: an up to date review. Rev. Environ. Sci. Bio/Technol. 10:215. doi: 10.1007/s11157-011-9244-9

Tyagi, V. K., and Lo, S.-L. (2013). Sludge: a waste or renewable source for energy and resources recovery? Renew. Sustain. Energy Rev. 25, 708-728. doi: 10.1016/j.rser.2013.05.029

Tyl, R. W., Myers, C. B., Marr, M. C., Thomas, B. F., Keimowitz, A. R., Brine, D. R., et al. (2002). Three-generation reproductive toxicity study of dietary bisphenol A in CD Sprague-Dawley rats. Toxicol. Sci. 68, 121-146. doi: $10.1093 /$ toxsci/68.1.121

USEPA (2009). Targeted National Sewage Sludge Survey Sampling and Analysis Technical Report. USEPA.

Ushani, U., Banu, J. R., Kavitha, S., Kaliappan, S., and Yeom, I. T. (2017a). Immobilized and MgSO 4 induced cost effective bacterial disintegration of waste activated sludge for effective anaerobic digestion. Chemosphere 175, 66-75. doi: 10.1016/j.chemosphere.2017.02.046

Ushani, U., Banu, J. R., Tamilarasan, K., Kavitha, S., and Yeom, I. T. (2017b). Surfactant coupled sonic pretreatment of waste activated sludge for energetically positive biogas generation. Bioresour. Technol. 241, 710-719. doi: 10.1016/j.biortech.2017.05.201

Ushani, U., Kavitha, S., Johnson, M., Yeom, I. T., and Banu, J. R. (2017c). Upgrading the hydrolytic potential of immobilized bacterial pretreatment to boost biogas production. Environ. Sci. Pollut. Res. 24, 813-826. doi: 10.1007/s11356-016-7819-2

Ushani, U., Kavitha, S., Kannah, R. Y., Gunasekaran, M., Kumar, G., Nguyen, D. D., et al. (2018). Sodium thiosulphate induced immobilized bacterial disintegration of sludge: an energy efficient and cost effective platform for sludge management and biomethanation. Bioresour. Technol. 260, 273-282. doi: 10.1016/j.biortech.2018.03.118

Vaithyanathan, V. K., Cabana, H., and Vaidyanathan, V. K. (2021a). Remediation of trace organic contaminants from biosolids: influence of various pretreatment strategies prior to Bacillus subtilis aerobic digestion. Chem. Eng. J. 2021:129966. doi: 10.1016/j.cej.2021.129966 
Vaithyanathan, V. K., Ravi, S., Leduc, R., Vaidyanathan, V. K., and Cabana, H. (2020). Utilization of biosolids for glucose oxidase production: a potential bio-fenton reagent for advanced oxidation process for removal of pharmaceutically active compounds. J. Environ. Manage. 271:110995. doi: 10.1016/j.jenvman.2020.110995

Vaithyanathan, V. K., Savary, O., and Cabana, H. (2021b). Performance evaluation of biocatalytic and biostimulation approaches for the remediation of trace organic contaminants in municipal biosolids. Waste Manage. 120, 373-381. doi: 10.1016/j.wasman.2020.11.046

Valentino, F., Moretto, G., Lorini, L., Bolzonella, D., Pavan, P., and Majone, M. (2019). Pilot-scale polyhydroxyalkanoate production from combined treatment of organic fraction of municipal solid waste and sewage sludge. Ind. Eng. Chem. Res. 58, 12149-12158. doi: 10.1021/acs.iecr.9b01831

Verlicchi, P., Al Aukidy, M., and Zambello, E. (2012). Occurrence of pharmaceutical compounds in urban wastewater: removal, mass load and environmental risk after a secondary treatment-a review. Sci. Total Environ. 429, 123-155. doi: 10.1016/j.scitotenv.2012.04.028

Verlicchi, P., and Zambello, E. (2015). Pharmaceuticals and personal care products in untreated and treated sewage sludge: occurrence and environmental risk in the case of application on soil-a critical review. Sci. Total Environ. 538, 750-767. doi: 10.1016/j.scitotenv.2015.08.108

Vidyarthi, A. S., Tyagi, R. D., Valero, J. R., and Surampalli, R. Y. (2002). Studies on the production of $B$. thuringiensis based biopesticides using wastewater sludge as a raw material. Water Res. 36, 4850-4860. doi: 10.1016/S0043-1354(02)00213-0

Vogel, T. M. (1996). Bioaugmentation as a soil bioremediation approach. Curr. Opin. Biotechnol. 7, 311-316. doi: 10.1016/S0958-1669(96)80036-X

Wainaina, S., Awasthi, M. K., Sarsaiya, S., Chen, H., Singh, E., Kumar, A., et al. (2020). Resource recovery and circular economy from organic solid waste using aerobic and anaerobic digestion technologies. Bioresour. Technol. 301:122778. doi: 10.1016/j.biortech.2020.122778

Wang, Q., Wei, W., Liu, S., Yan, M., Song, K., Mai, J., et al. (2018). Free ammonia pretreatment improves degradation of secondary sludge during aerobic digestion. ACS Sustain. Chem. Eng. 6, 1105-1111. doi: 10.1021 acssuschemeng. $7 \mathrm{~b} 03403$

Wang, X., Li, Y., Li, R., Yang, H., Zhou, B., Wang, X., et al. (2019). Comparison of chlorination behaviors between norfloxacin and ofloxacin: reaction kinetics, oxidation products and reaction pathways. Chemosphere 215, 124-132. doi: 10.1016/j.chemosphere.2018.09.100

Wang, Y., Feng, S., Bai, X., Zhao, J., and Xia, S. (2016). Scum sludge as a potential feedstock for biodiesel production from wastewater treatment plants. Waste Manage. 47, 91-97. doi: 10.1016/j.wasman.2015.06.036

WEAO (2010). Optimisation Guidance Manual for Sewage Works. Water Environment Association of Ontario, Ontario Ministry of the Environment, Environment Canada.

Xiao, K., Chen, Y., Jiang, X., Seow, W. Y., He, C., Yin, Y., et al. (2017). Comparison of different treatment methods for protein solubilisation from waste activated sludge. Water Res. 122, 492-502. doi: 10.1016/j.watres.2017.06.024

Xue, W., Zeng, Q., Lin, S., Zan, F., Hao, T., Lin, Y., et al. (2019). Recovery of high-value and scarce resources from biological wastewater treatment: sulfated polysaccharides. Water Res. 163:114889. doi: 10.1016/j.watres.2019.114889

Yang, Z., Wang, W., Liu, C., Zhang, R., and Liu, G. (2019). Mitigation of ammonia inhibition through bioaugmentation with different microorganisms during anaerobic digestion: selection of strains and reactor performance evaluation. Water Res. 155, 214-224. doi: 10.1016/j.watres.2019.02.048

Yezza, A., Tyagi, R. D., Valero, J. R., and Surampalli, R. Y. (2005). Production of Bacillus thuringiensis-based biopesticides in batch and fed batch cultures using wastewater sludge as a raw material. J. Chem. Technol. Biotechnol. 80, 502-510. doi: $10.1002 / j$ ctb. 1204

Yezza, A., Tyagi, R. D., Valero, J. R., and Surampalli, R. Y. (2006). Bioconversion of industrial wastewater and wastewater sludge into Bacillus thuringiensis based biopesticides in pilot fermentor. Bioresour. Technol. 97, 1850-1857. doi: 10.1016/j.biortech.2005.08.023

Yu, G.-H., He, P.-J., Shao, L.-M., and Zhu, Y.-S. (2008). Extracellular proteins, polysaccharides and enzymes impact on sludge aerobic digestion after ultrasonic pretreatment. Water Res. 42, 1925-1934. doi: 10.1016/j.watres.2007.11.022
Yu, G.-H., He, P. J., and Shao, L. M. (2009). Characteristics of extracellular polymeric substances (EPS) fractions from excess sludges and their effects on bioflocculability. Bioresour. Technol. 100, 3193-3198. doi: 10.1016/j.biortech.2009.02.009

Yu, S., Zhang, G., Li, J., Zhao, Z., and Kang, X. (2013). Effect of endogenous hydrolytic enzymes pretreatment on the anaerobic digestion of sludge. Bioresour. Technol. 146, 758-761. doi: 10.1016/j.biortech.2013. 07.087

Yu, X., Shi, J., Khan, A., Yun, H., Zhang, P., Zhang, P., et al. (2020). Immobilizedmicrobial bioaugmentation protects aerobic denitrification from heavy metal shock in an activated-sludge reactor. Bioresour. Technol. 307:123185. doi: 10.1016/j.biortech.2020.123185

Zhang, J., Bao, Y., Jiang, Y., Liu, H. T., Xi, B. D., and Wang, D. Q. (2019). Removal and dissipation pathway of typical fluoroquinolones in sewage sludge during aerobic composting. Waste Manage. 95, 450-457. doi: 10.1016/j.wasman.2019.06.036

Zhang, R., Zhu, F., Dong, Y., Wu, X., Sun, Y., Zhang, D., et al. (2020). Function promotion of $\mathrm{SO} 42-/ \mathrm{Al} 2 \mathrm{O} 3-\mathrm{SnO} 2$ catalyst for biodiesel production from sewage sludge. Renew. Energy 147, 275-283. doi: 10.1016/j.renene.2019. 08.141

Zhang, W., Alvarez-Gaitan, J. P., Dastyar, W., Saint, C. P., Zhao, M., and Short, M. D. (2018). Value-added products derived from waste activated sludge: a biorefinery perspective. Water 10:545. doi: 10.3390/w10050545

Zhang, X., Yan, S., Tyagi, R. D., Drogui, P., and Surampalli, R. Y. (2016). Ultrasonication aided biodiesel production from one-step and two-step transesterification of sludge derived lipid. Energy 94, 401-408. doi: 10.1016/j.energy.2015.11.016

Zhang, X., Yan, S., Tyagi, R. D., Surampalli, R. Y., and Valéro, J. R. (2014). Lipid production from Trichosporon oleaginosus cultivated with pre-treated secondary wastewater sludge. Fuel 134, 274-282. doi: 10.1016/j.fuel.2014.05.089

Zhen, G., Lu, X., Kato, H., Zhao, Y., and Li, Y.-Y. (2017). Overview of pretreatment strategies for enhancing sewage sludge disintegration and subsequent anaerobic digestion: current advances, full-scale application and future perspectives. Renew. Sustain. Energy Rev. 69, 559-577. doi: 10.1016/j.rser.2016. 11.187

Zhou, H., Liu, J., Chen, X., Ying, Z., Zhang, Z., and Wang, M. (2018). Fate of pharmaceutically active compounds in sewage sludge during anaerobic digestions integrated with enzymes and physicochemical treatments. Waste Manage. 78, 911-916. doi: 10.1016/j.wasman.2018.07.018

Zhou, H., Zhang, Z., Wang, M., Hu, T., and Wang, Z. (2017). Enhancement with physicochemical and biological treatments in the removal of pharmaceutically active compounds during sewage sludge anaerobic digestion processes. Chem. Eng. J. 316, 361-369. doi: 10.1016/j.cej.2017.01.104

Zhuang, L., Zhou, S., Wang, Y., and Chang, M. (2011). Mosquito biolarvicide production by sequential fermentation with dual strains of Bacillus thuringiensis subsp. israelensis and Bacillus sphaericus using sewage sludge. Bioresour. Technol. 102, 1574-1580. doi: 10.1016/j.biortech.2010.08.090

Conflict of Interest: The authors declare that the research was conducted in the absence of any commercial or financial relationships that could be construed as a potential conflict of interest.

Publisher's Note: All claims expressed in this article are solely those of the authors and do not necessarily represent those of their affiliated organizations, or those of the publisher, the editors and the reviewers. Any product that may be evaluated in this article, or claim that may be made by its manufacturer, is not guaranteed or endorsed by the publisher.

Copyright (c) 2021 Vaithyanathan and Cabana. This is an open-access article distributed under the terms of the Creative Commons Attribution License (CC BY). The use, distribution or reproduction in other forums is permitted, provided the original author(s) and the copyright owner(s) are credited and that the original publication in this journal is cited, in accordance with accepted academic practice. No use, distribution or reproduction is permitted which does not comply with these terms. 